\title{
HOUSE FINCHES, CARPODACUS MEXICANUS: HORMONES, STRESS, AND SONG CONTROL REGIONS
}

\author{
A Thesis \\ presented to \\ the Faculty of California Polytechnic State University, \\ San Luis Obispo
}

\author{
In Partial Fulfillment \\ of the Requirements for the Degree \\ Master of Science in Biological Sciences
}

by

Katherine Olivia Ganster

December 2012 
(C) 2012

Katherine Olivia Ganster

ALL RIGHTS RESERVED

ii 


\title{
COMMITTEE MEMBERSHIP
}

TITLE:

AUTHOR:

DATE SUBMITTED:

Katherine Olivia Ganster

and Song Control Regions

House Finches, Carpodacus mexicanus: Hormones, Stress,

\author{
and Song Control Regions
}

Katherine Olivia Ganster

December 2012

COMMITTEE CHAIR: $\quad$ Christy R. Strand, PhD

COMMITTEE MEMBER: Emily Taylor, PhD

COMMITTEE MEMBER: Francis Villablanca, PhD 


\begin{abstract}
House Finches, Carpodacus mexicanus: Hormones, Stress, and Song Control Regions

Katherine Olivia Ganster
\end{abstract}

Song production in songbirds is controlled by parts of the brain known as the song control regions (SCRs). During spring, gonads increase in size, males sing to attract mates, and SCRs become larger. This neuroplasticity is controlled by the change in day length and increased plasma testosterone (T) levels. Plasma T can be reduced by stress through the production of corticosterone (CORT), through the production of betaendorphin, or through direct effects on the testes via the nervous system. We determined the T, estradiol, and CORT hormonal profiles of wild House Finches by capturing and sampling blood from the finches every season for two years. To track SCR neuroplasticity in the wild, we also measured the volume of two specific SCRs, the HVC and RA, every season. We then examined the effects of stress on the finch endocrine system in the wild by performing a 30-minute restraint stress protocol once every season and took blood samples before and after the restraint. To determine whether stress and/or CORT affect neuroplasticity in SCRs, we captured male house finches during winter and brought them into captivity. They were allowed to acclimate to captivity for one month on short days (8L:16D) before we transferred them to long days (16L:8D) and restraint stressed half the birds. We measured their gonads, plasma T and CORT levels, volumes of the HVC and $\mathrm{RA}$, and the number of new neurons in the HVC. HVC volumes were smaller in stressed than non-stressed birds, while RA volumes did not differ. There was no difference in number of new neurons or estimated total number of neurons in the HVC between control and restrained birds. Because the HVC is involved in song production, it is possible that stress negatively impacts singing behavior and reproductive success in House Finches. Future work should address how natural stressors may affect neuroplasticity in birds.

Keywords: Songbird, Stress, Song control region, Neuroplasticity, Neurogenesis, hormonal profile 


\section{ACKNOWLEDGMENTS}

I thank Gennarina Riso, Monica Mills, Jenna Petersen, Annie Schiowitz, Leandra Conley, Ben Gamache, Brandon Bautista, Tyler Simpson, Julius “Tony” Frazier, Thomas Bales, Nicholas Pollock, Brandon Ganster, Leilani Lucas, Susannah French PhD, Karen McGaughey PhD, Doug Brewster, Mike Curto, Maddie Nix and everyone in the Cal Poly Biology Department, the helpful attendees of the 2011 Society for Integrative and Comparative Biology conference, especially Michael Romero PhD and Jon Wingfield PhD, and my committee members: Christy Strand PhD, Emily Taylor PhD, and Francis Villablanca PhD. 


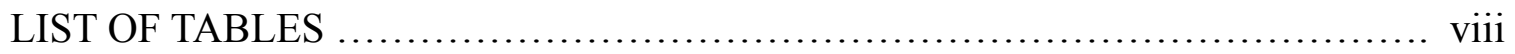

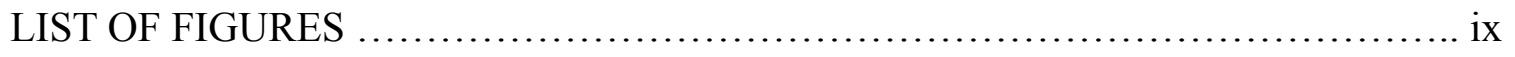

\section{CHAPTER}

I. Hormonal profiles of House Finches, Carpodacus mexicanus, and the effects of stress on the SCRs and HPG axis ................................ 1

Materials and Methods ............................................ 5

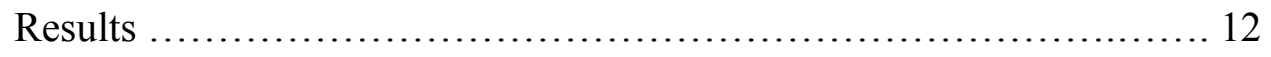

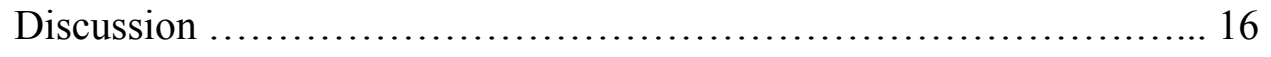

Tables and Figures ................................................... 27

II. Stress affects song control nuclei growth in adult male House Finches,

Carpodacus mexicanus .................................................... 36

Materials and Methods ............................................ 42

Results ...................................................... 48

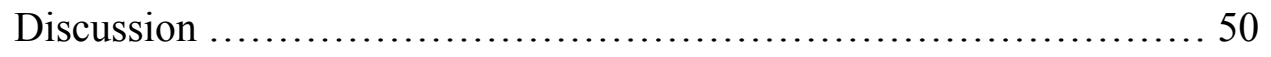

Tables and Figures ................................................ 56

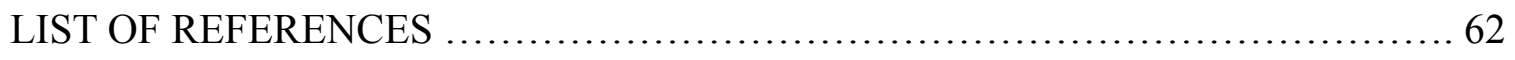




\section{LIST OF TABLES}

Table

\section{CHAPTER I}

1. Photoperiods and their associated dates, as determined for our field site during 2009 and 2010

2. Breeding periods and their associated dates, as determined for our field site during 2009 and 2010

3. Sample sizes of hormone data from wild House Finches .................... 28

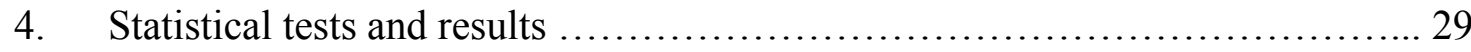




\section{LIST OF FIGURES}

Figure

Page

\section{CHAPTER I}

1. Seasonal profile of testosterone $(\mathrm{ng} / \mathrm{ml}$; mean $+/-\mathrm{se})$ of male House

Finches from February 2009 to January 2011 (n=2-9/sample) 30

2. Seasonal profile of estradiol ( $\mathrm{ng} / \mathrm{ml}$; mean $+/-\mathrm{se})$ of female House

Finches from March 2009 to January 2011 (n=2-8/sample)

3. Cloacal protuberance diameter $(\mathrm{mm})$ of male House Finches from January

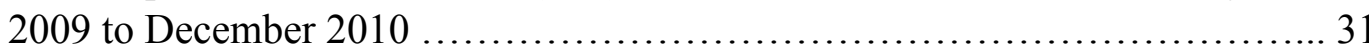

4. HVC volumes $\left(\mathrm{mm}^{3}\right.$, mean $\left.+/-\mathrm{se}\right)$ from male House Finches on February 7th (photosensitive), March 21st (photostimulated), and July 18th (photorefractory) of 2009

5. RA volumes $\left(\mathrm{mm}^{3}\right.$, mean $\left.+/-\mathrm{se}\right)$ from male House Finches on February 7th (photosensitive), March 21st (photostimulated), and July 18th (photorefractory) of 2009

6. Plasma CORT concentrations ( $\mathrm{ng} / \mathrm{ml}$; mean $+/-\mathrm{se}$ ) from male and female House Finches before and after they were restrained in a bag for 30 minutes .... 33

7. Plasma T concentrations (ng/ml; mean +/- se) from male House Finches before and after they were restrained in a bag for 30 minutes

8. Plasma $\mathrm{E}_{2}$ concentrations ( $\mathrm{ng} / \mathrm{ml}$; mean $+/-\mathrm{se}$ ) from female House Finches before and after they were restrained in a bag for 30 minutes 35

\section{CHAPTER II}

1. Schematic diagram of the songbird brain (Image from Nottebohm, 2002) ...... 56

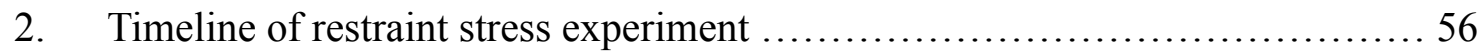

3. Plasma corticosterone ( $\mathrm{ng} / \mathrm{ml}$; mean $+/-$ se) in male House Finches during the four week acclimation period

4. Plasma testosterone (ng/ml; mean $+/-\mathrm{se})$ in male House Finches on days 1 and 6 of the restraint stress experiment 
5. Plasma corticosterone ( $\mathrm{ng} / \mathrm{ml}$; mean $+/$ - se) in male House Finches on day 1 and day 6 of the experiment before and 30 minutes after treatment 59

6. HVC volumes $\left(\mathrm{mm}^{3}\right.$; mean $\left.+\mathrm{se}\right)$ in the control and restraint group ............. 59

7. RA volumes $\left(\mathrm{mm}^{3}\right.$; mean $\left.+\mathrm{se}\right)$ in the control and restraint group $(\mathrm{p}=0.31) \ldots \ldots 60$

8. DCX cell density (cells $/ \mathrm{mm}^{3}$ ) in the HVC of control and restrained birds

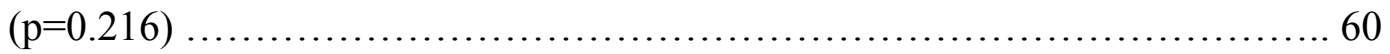

9. Estimated total of new neurons in the HVC of control and restrained birds

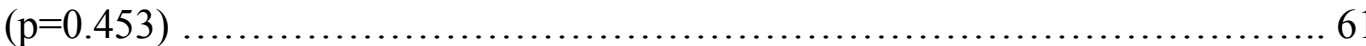


I.

\section{Hormonal profiles of House Finches, Carpodacus mexicanus, and the effects of stress on the SCRs and HPG axis}

\section{Introduction}

Songbird behaviors, such as singing and breeding, depend on hormonal cues, which are altered by photoperiod. During spring, as photoperiod increases, the change in day length activates the hypothalamic-pituitary-gonadal (HPG) axis, by causing the release of gonadotropin releasing hormone $(\mathrm{GnRH})$ from the hypothalamus (see review: Wingfield and Sapolsky, 2003). Higher levels of GnRH increase the production of luteinizing hormone $(\mathrm{LH})$ and follicle stimulating hormone (FSH) from the adenohypophysis (see review: Wingfield and Sapolsky, 2003). Photostimulation, along with increased $\mathrm{LH}$ and $\mathrm{FSH}$, ultimately stimulates the growth of the gonads and results in increased levels of testosterone $(\mathrm{T})$ and estradiol $\left(\mathrm{E}_{2}\right)$ in males and females, respectively (see review: Wingfield and Sapolsky, 2003).

Photostimulation, along with increasing $\mathrm{T}$, initiates a suite of physiological and behavioral responses, including the enlargement of telencephalic nuclei called song control regions (SCRs) in male songbirds (Nottebohm, 1981; Bernard and Ball, 1997; Smith et al., 1997a; and 1997b; Gulledge and Deviche, 1998; Bentley et al., 1999; Whitfield-Rucker and Cassone, 2000; Dloniak and Deviche, 2001; Tramontin et al., 2001; Caro et al., 2005; Sartor et al., 2005; Strand and Deviche, 2007; also see review:

Wilson and Donham, 1988). Collectively, SCRs are responsible for the learning, production, and maintenance of song (Nottebohm, 1981). In this study, we focused on 
two SCRs, the HVC (acronym used as common name), which controls song learning and production, and the robust nucleus of the arcopallium (RA), which is involved in song output (Nottebohm et al., 1976; Scharff and Nottebohm, 1991).

The growth of SCRs is stimulated by increased photoperiod, independent of high plasma T, in Gambel's White-crowned Sparrows (Smith et al., 1997b), American tree sparrows (Bernard et al., 1994), House Sparrows (Whitfield-Rucker and Cassone, 2000), Song Sparrows (Tramontin et al., 2001), Dark-eyed Juncos (Gulledge and Deviche, 1998; Dloniak and Deviche, 2001), European Starlings (Bentley et al., 1999), and Corsican Blue Tits (Caro et al., 2005). However, the growth of the HVC in Common Canaries occurs from increased T, without photostimulation (Sartor et al., 2005), and T increases the volume of the HVC in Dark-eyed Juncos under certain conditions (Dloniak and Deviche, 2001). In photosensitive House Finches, increased T enlarges the volume of the HVC and RA (Strand and Deviche, 2007). Increased photoperiod enlarges House Finch RA volume but not HVC volume (Strand and Deviche, 2007). Increased T, and possibly enlarged SCRs, leads to increased singing behavior in male songbirds (Gulledge and Deviche, 1998; Dloniak and Deviche, 2001; Sartor et al., 2005; Strand et al., 2008; also see review: Ball et al., 2002). In females, photostimulation causes the development of ovarian follicles, a brood patch, and receptiveness to males' singing and copulation solicitation display (Kroodsma, 1976; Morton et al., 1985; Bentley et al., 2000; Sockman et al., 2004; Caro et al., 2010).

By mid-summer, long photoperiods no longer stimulate the HPG axis, in a phenomenon called photorefractoriness (review: Ball and Balthazart, 2002). During the 
photorefractory period, GnRH, LH, and FSH levels decrease, causing gonads to regress (Hamner, 1968; also see reviews: Dawson et al., 2001; Meitzen and Thompson, 2008). During this time SCRs start to decrease in volume, returning to a non-breeding state, and male song production decreases (Nottebohm, 1981; Kirn et al., 1989; Smith et al., 1997a; Smith et al., 1997b; see review: Meitzen and Thompson, 2008). To reinstate photosensitivity, birds must be exposed to days with a limited amount of light, as experienced through winter (review: Ball and Balthazart, 2002).

Before spring (pre-breeding; January-March), House Finch pair formation occurs (Thompson, 1960). House Finch breeding begins mid-March, when nest-building commences, and continues with egg laying until late July (Hill, 1993). The male House Finch attends to his young for a few days after they have fledged, until they are independent; during this time, the female may begin laying another clutch (Hill, 1993). The majority of female House Finches nest more than once in a single breeding season (Evenden, 1957); thus males continue singing after their first pair bonding (Hill, 1991). Interestingly, the hormonal control of breeding behaviors can be altered by other physiological factors, such as stress.

The physiological impact of stress begins with the release of corticotropinreleasing factor via the hypothalamic-pituitary-adrenal (HPA) axis. This hormone causes the release of adrenocorticotropic hormone (ACTH) from the adenohypophysis, which, in turn, causes the release of a glucocorticosteroid hormone called corticosterone (CORT) from the adrenal cortex (Wingfield et al., 1982; 1983; 1994; 1995; also see reviews: Siegel, 1980; Harvey et al., 1984; Wingfield and Sapolsky, 2003). High CORT levels 
decrease plasma T (Dong et al., 2004; Hardy et al., 2005; Deviche et al., 2010; also see review: Wingfield and Sapolsky, 2003). Because high plasma T induces song production, the T-inhibiting effects of stress may hinder male reproductive behaviors and their breeding success.

Stress may effectively postpone breeding in birds that live in favorable environments and/or have long breeding seasons because these species have extended resources and time to reinstate breeding behavior (Morton, 1976; Hahn et al., 1997; Breuner et al., 2003). Stress may not delay breeding in birds that live in harsh environments and/or have short breeding seasons because these birds do not have excess time to reproduce (Morton, 1976; Wingfield et al., 1992; Breuner et al., 2003). Therefore House Finches, being in the former category, may be representative of birds that are more prone to stress-related breeding delays.

Although general hormonal interactions have been extensively studied, details on intra- and inter-annual variation in $\mathrm{T}, \mathrm{E}_{2}$, and CORT are not well known. This study investigates the amount of variability of these hormones in House Finches from year to year, and relates the changes in these hormones to both physiological and behavioral responses. We captured adult male and female House Finches and determined the intraand inter-annual differences of $\mathrm{T}, \mathrm{E}_{2}$, and CORT, and measured the stress response and SCR volumes during photosensitive, photostimulated and photorefractory time periods. This information will provide new insight into yearly and seasonal variation in reproductive and stress hormones. The House Finch serves as a good comparative model species for hormonal research because most avian hormonal research is performed on 
birds that are either migratory and/or territorial; House Finches are gregarious, generally non-migratory and non-territorial. Furthermore, they are widespread, abundant and easy to catch and maintain in captivity.

We expected males to have high plasma $\mathrm{T}$ and females to have high plasma $\mathrm{E}_{2}$ during the breeding season (photostimulated) compared to other times of the year. We expected the SCRs, HVC and RA, to be larger during the breeding season (photostimulated) than at other times of the year, and we expected the HVC and RA to regress at the onset of photorefractoriness. We hypothesized that stress/CORT would affect plasma $\mathrm{T}$ seasonally. We predicted breeding (photostimulated) $\mathrm{T}$ levels would decrease after stress and/or CORT but expected non-breeding (photosensitive, photorefractory) $\mathrm{T}$ levels to be too low to be affected by stress/CORT and/or too low to allow us to detect an appreciable decrease.

\section{Materials and Methods}

\subsection{Hormonal profiles and body condition}

We captured adult House Finches in Santa Margarita, California (34.953N, -120.434W) every other week between February 2009 and July 2010, and every month from August 2010 to December 2010. Six to twenty-one birds were caught on any given sampling day, with an average of 12.5 birds per day. More than ten birds were caught per day $80 \%$ of the time. To capture, we used a closable, cylindrical wire cage with black oil 
sunflower seeds as bait. Most birds were collected within three minutes of being caught in the trap, and all birds were weighed. If birds were collected and weighed within three minutes of capture, a $200 \mu \mathrm{l}$ blood sample was collected via alar vein puncture into microhematocrit tubes. No individual bird was bled more than once per month. All House Finches were banded using United States Geological Survey (USGS) bird bands, sizes 1-1B. All birds' body condition - age, sex, molt status, fat reserves (on a scale of 1 to 3), cloacal protuberance (CP) (males; mm), and brood patch (females; on a scale of 1 to 3 , if applicable) - were determined and recorded before birds were set free. Body condition measurements were used to determine when photoperiods and seasons began and ended (forming Tables 1 and 2). Blood samples were stored at $4^{\circ} \mathrm{C}$ until they were transported 19 miles to California Polytechnic State University, San Luis Obispo, and centrifuged. Plasma was collected and stored at $-20^{\circ} \mathrm{C}$.

All procedures were approved by the California Polytechnic State University Institutional Animal Care and Use Committee. Scientific collecting permits were secured from the California Department of Game and Fish and the United States Fish and Wildlife Service before collection.

\subsection{Song control regions}

On February 7 (photosensitive), March 21 (photostimulated), and July 18 (photorefractory) of 2009 (Table 1), captured male House Finches $(n=6, n=4$, and $n=6$, 
respectively) were weighed and their age, molt status, fat reserves, and $\mathrm{CP}$ were measured.

The day after they were caught, House Finches were sacrificed via isoflurane inhalation, followed by perfusion with saline $(0.9 \%$ sodium chloride in $0.1 \mathrm{M}$ phosphate buffer (PB) with $0.1 \%$ sodium nitrite) and then $4 \%$ paraformaldehyde in $0.1 \mathrm{M}$ PB with $0.1 \%$ sodium nitrite. Their brains were extracted from the skull, then post-fixed and stored in $4 \%$ paraformaldehyde in $0.1 \mathrm{M} \mathrm{PB}$ at $4{ }^{\circ} \mathrm{C}$ overnight. The next day, brains were blotted dry, weighed to the nearest milligram, embedded in $8 \%$ gelatin and stored in $4 \%$ paraformaldehyde in $0.1 \mathrm{M} \mathrm{PB}$ overnight at $4^{\circ} \mathrm{C}$. Embedded brains were transferred to $30 \%$ sucrose solution for 36 hours at $4^{\circ} \mathrm{C}$ and then frozen on dry ice and stored at $-80^{\circ} \mathrm{C}$ until sectioning.

Brains were sectioned coronally at $40 \mu \mathrm{m}$ on a cryostat $\left(-16^{\circ} \mathrm{C}\right)$ in four parallel series. Free-floating sections were stored in cryoprotectant solution (Watson et al., 1986) at $-20^{\circ} \mathrm{C}$ until processed. We immunostained sections containing the $\mathrm{HVC}$ from the first series of each brain for the neuronal marker NeuN to measure the volume of the HVC and RA. Briefly, sections were rinsed in $\mathrm{PB}$, incubated in a $0.5 \%$ hydrogen peroxide and 5\% normal horse serum solution (Vector Labs, Burlingame, CA) for 1 hour, and then incubated in 1:10,000 mouse monoclonal anti-NeuN IgG (Chemicon International, Temecula, CA) in $0.3 \%$ Triton X-100 (Fisher Scientific, Fair Lawn, NJ) in $0.1 \mathrm{M}$ PB (PBT) overnight at $4^{\circ} \mathrm{C}$. The next day, sections were rinsed in PBT, incubated in 1:500 biotinylated anti-mouse IgG (Vector Labs) in PBT for 1 hour, rinsed in PBT, incubated in $\mathrm{ABC}$ solution (Vector Labs) for 1 hour, and then rinsed in PBT. Immunoproducts were 
visualized by incubating sections in Vector SG chromagen solution (Vector Labs) for 2 minutes. Sections were rinsed in $0.9 \%$ sodium chloride (Fisher Scientific) in $0.01 \mathrm{M}$ PB (PBS), mounted onto slides, dried overnight, and coverslipped. To validate the specificity of the immunostaining procedure, control sections were incubated without primary or secondary antibody. No immunostaining was observed in any control section.

A Leica EZ4D microscope was used at 35x magnification to digitize images of NeuN sections containing the HVC, and an Olympus BX60 microscope was used at 40x magnification to digitize images of the RA. The cross sectional areas of the HVC and RA were delineated from digital images and electronically calculated using ImageJ version 1.410 software (National Institutes of Health, USA). The area of each brain region was calculated for the left and right hemispheres on each section and then summed. Volumes were calculated by multiplying the summed areas by the distance separating consecutive sections $(160 \mu \mathrm{m})$. If a section was lost or damaged ( $\mathrm{n}=5$ out of 209 sections for HVC, $\mathrm{n}=3$ out of 140 sections for RA), the corresponding measurement was replaced by the average of the two areas in the adjacent sections.

\subsection{Stress Response}

On March 4 and April 2 (photostimulated; males $n=6$; females $n=7$ ), August 12 and 13 (photorefractory; males $\mathrm{n}=7$; females $\mathrm{n}=2$ ), and December 12 (photosensitive; males $n=3$; females $n=3$ ) of 2010 (Table 1), male and female House Finches were caught,

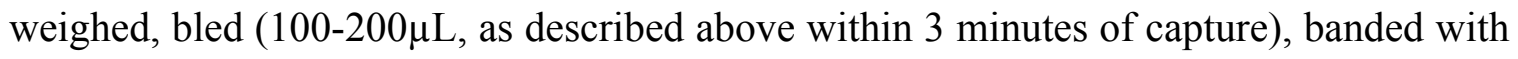


USGS bands (size 1-1B), and restrained individually in opaque cloth bags for 30 minutes. After the 30 minute restraint, a second $100-200 \mu \mathrm{L}$ blood sample was collected. Molt, age, $\mathrm{CP}$ (male), and brood patch (female) were measured and recorded before birds were released. Blood samples were stored at $4^{\circ} \mathrm{C}$ until they were transported 19 miles to California Polytechnic State University, San Luis Obispo, and centrifuged. Plasma was collected and stored at $-20^{\circ} \mathrm{C}$ until measured for $\mathrm{T}, \mathrm{E}_{2}$, and CORT concentrations.

\subsection{Radioimmunoassay}

Radioimmunoassay (RIA) was performed on blood plasma samples at Utah State University, Logan, UT. Two RIA assays were used. All 2010 samples and most 2009 samples (randomly assigned) for $\mathrm{T}, \mathrm{E}_{2}$, and CORT were performed in a single assay. The remaining 2009 plasma $T$ samples and restraint-stress $T$ samples were assigned to the second assay. Plasma samples were assayed for $\mathrm{T}$ and CORT for male birds and $\mathrm{E}_{2}$ and CORT for female birds, using a previously described and established laboratory protocol (Moore, 1986). In brief, samples were extracted using 30\% ethyl acetate/isooctane extractions. The $30 \%$ phase was separated, dried and resuspended in $10 \%$ ethyl acetate in isooctane. Individual hormones were separated from samples using packed columns. Different elutions of ethyl acetate/isooctane were added to the columns to separate out the different hormones (20\% for testosterone; $52 \%$ for CORT). Separated samples were collected in vials, dried and resuspended in PBS buffer. Duplicate aliquots of these samples were then assayed for $\mathrm{T}$ and CORT. The intra-assay coefficients of variation 
(CV) for the first assay were $9.2 \%$ for $\mathrm{T}, 18.3 \%$ for $\mathrm{E}_{2}$, and $7.2 \%$ for CORT; the intraassay CV for the second assay were $14.7 \%$ for the remaining $2009 \mathrm{~T}$ data and $4.9 \%$ for pre- and post-stress $\mathrm{T}$ data.

\subsection{Data Analysis}

We used ANOVA to analyze plasma $\mathrm{T}$ (males) and $\mathrm{E}_{2}$ (females) seasonal hormone data from all birds (caught and released) from February 2009 through December 2010. We did the same for CP diameters of male birds. Of the 226 different birds caught, 91 were recaptured at least once. Most recaptures were caught fewer than three times, thus making repeated measures analyses not possible on all data. We analyzed the data in two ways. First, analyses were completed via one-way ANOVA by systematically removing data from repeated birds to maximize sample numbers for each sampling date (Table 4). To determine differences between sampling dates, we performed an unequal $\mathrm{n}$ honestly significant difference (HSD) test on $\mathrm{CP}$ diameters, plasma $\mathrm{T}$, and plasma $\mathrm{E}_{2}$ (performed if the one-way ANOVA was significant; $\mathrm{CP}, \mathrm{T}$, and $\mathrm{E}_{2}$ analyzed separately). Plasma $\mathrm{T}$ data were $\log (10)$ transformed. Second, we analyzed the hormone data by performing a repeated measures ANOVA, categorizing the data by season (pre-breeding, breeding, molt, and non-breeding) instead of sampling date (Table 2). In order to run the repeated measures analysis with maintaining as much data as possible, we deleted values of birds not caught in at least two different seasons within the same year and analyzed the years (2009-2010) separately (Tables 3 and 4). To determine hormonal differences between 
seasons, we performed an unequal $\mathrm{n}$ HSD test on plasma $\mathrm{T}$ and $\mathrm{E}_{2}$. No bird was recaptured every season. Because of this, the repeated measures ANOVA on T in 2009 analyzed breeding, molt, and non-breeding seasons alone (not including pre-breeding due to lack of repeated captures). Similarly, the 2010 repeated measures ANOVA on T analyzed pre-breeding, breeding, and molt (not including non-breeding data). All plasma T data was $\log (10)$ transformed. Females were not recaptured in enough seasons during 2009 to run a repeated measures ANOVA on $\mathrm{E}_{2}$. The repeated measures ANOVA on 2010 $\mathrm{E}_{2}$ data analyzed pre-breeding, breeding, and molt (not including non-breeding due to lack of repeated captures). The repeated measures ANOVA on 2009 CP diameters could not be performed on all four seasons in a single analysis. Therefore, two analyses were performed; the first included all seasons except molt, and the second included all seasons except pre-breeding. The repeated measures ANOVA on $2010 \mathrm{CP}$ diameters did not include non-breeding data.

For the 2010 restraint stress experiment, we used repeated measures ANOVA to examine the effect of photoresponsiveness on CORT, $\mathrm{T}$, and $\mathrm{E}_{2}$ responses to stress (each hormone analyzed separately). To determine hormonal differences between photoperiods and between times (before vs. after restraint), we performed an unequal n HSD test on plasma CORT, $\mathrm{T}$ and $\mathrm{E}_{2}$ (analyzed separately). Because plasma $\mathrm{T}$ is higher during breeding and at extremely low levels during other times, we analyzed the effect of the stress response on plasma $\mathrm{T}$ during photostimulation via a paired t-test. All restraint-stress plasma T data were $\log (10)$ transformed. 
We performed a one way ANOVA to examine the effect of photoresponsiveness on the HVC and RA volumes of wild House Finches captured in 2009. To determine the differences in SCR volumes between photoperiods, we performed a Tukey HSD test.

All statistical tests were performed using Statistica (Version 10; StatSoft Inc., Tulsa, OK, USA).

\section{Results}

\subsection{Hormonal profiles and body condition}

Male $\mathrm{T}$ concentrations were affected by date from 2009 through $2010(\mathrm{~F}=3.18$; $\mathrm{df}=40,52 ; \mathrm{p}<0.0001$; Table 4 and Fig. 1 ), however the unequal $\mathrm{n}$ HSD test was unable to detect significant differences in plasma $\mathrm{T}$ between sampling dates. There was not an effect of season on plasma $\mathrm{T}$ in $2009(\mathrm{~F}=64.54 ; \mathrm{df}=1,1 ; \mathrm{p}=0.079)$, but there was an effect in 2010 ( $F=104.31 ; d f=1,6 ; p<0.0001$; Table 4 and Fig. 1). In 2010, molt plasma $\mathrm{T}$ was not different from pre-breeding levels $(\mathrm{p}=0.51)$, pre-breeding plasma $\mathrm{T}$ was not different from breeding levels $(\mathrm{p}=0.18)$, but there was a difference between breeding and molt $(\mathrm{p}=0.025)$.

Female House Finch $E_{2}$ levels were not affected by date from 2009 through 2010 $(\mathrm{F}=1.47 ; \mathrm{df}=37,17 ; \mathrm{p}=0.19$; Table 4 and Fig. 2$)$. Females were not recaptured in enough seasons during 2009 to analyze $\mathrm{E}_{2}$ via repeated measures ANOVA. In 2010 there was an 
effect of season on plasma $E_{2}(F=171.94 ; d f=1,2 ; p<0.01$; Table 4 and Fig. 2); however, the unequal $n$ HSD test was unable to detect significant differences between seasons (molt vs. pre-breeding, $\mathrm{p}=0.67$; pre-breeding vs. breeding, $\mathrm{p}=0.51$; breeding vs. molt, $\mathrm{p}=0.95)$.

Diameter of the CP was affected by date between 2009 and $2010(\mathrm{~F}=8.58$; $\mathrm{df}=40,59 ; \mathrm{p}<0.001 ;$ Table 4 and Fig. 3). In 2009 there was an effect of season on CP diameter, comparing pre-breeding, breeding, and non-breeding (molt not included; $\mathrm{F}=700.20 ; \mathrm{df}=1,4 ; \mathrm{p}<0.0001)$ and while comparing breeding, molt, and non-breeding (pre-breeding not included; $\mathrm{F}=491.50 ; \mathrm{df}=1,2 ; \mathrm{p}<0.001$; Table 4). In the first analysis (molt not included), CP diameter was larger during breeding than both pre-breeding $(\mathrm{p}=0.00072)$ and non-breeding $(\mathrm{p}=0.00022) ; \mathrm{CP}$ diameter was larger during pre-breeding than non-breeding $(\mathrm{p}=0.042)$. In the second analysis (pre-breeding not included), CP diameter was larger during breeding than non-breeding $(\mathrm{p}=0.031)$, but not molt $(\mathrm{p}=0.057)$; there was no difference between molt and non-breeding $(\mathrm{p}=0.76)$. In 2010, there was an effect of season on $\mathrm{CP}$ diameter $(\mathrm{F}=1747.41 ; \mathrm{df}=1,8 ; \mathrm{p}<0.00001$; Table 4 and Fig. 3). CP diameter was larger during breeding than pre-breeding ( $\mathrm{p}=0.00019)$; CP diameter was also larger during molt than pre-breeding $(\mathrm{p}=0.0014)$. There was no difference between breeding and molt $(\mathrm{p}=0.18)$.

\subsection{Seasonal SCR neuroplasticity}


There was an effect of photoresponsiveness on the mean HVC volumes of wild male House Finches in 2009 ( $F=3.88 ; d f=2,13 ; p=0.047$; Fig. 4). Photostimulated birds had a larger HVC than photorefractory birds ( $\mathrm{p}=0.038$; Fig. 4). The mean HVC of photosensitive birds was not different from photostimulated $(\mathrm{p}=0.20)$ or photorefractory $(\mathrm{p}=0.54)$ birds (Fig. 4).

There was also an effect of photoresponsiveness on the mean RA volumes $(\mathrm{F}=10.89 ; \mathrm{df}=2,13 ; \mathrm{p}=0.0016$; Fig. 5). Photostimulated birds had a larger RA than photorefractory $(\mathrm{p}=0.0026)$ and photosensitive $(\mathrm{p}=0.049)$ birds (Fig. 5). The mean RA of photorefractory and photosensitive birds was not different ( $\mathrm{p}=0.157$; Fig. 5).

\subsection{Restraint stress}

In the restraint stress experiment, there was not an effect of gender $(\mathrm{F}=1.08 ; \mathrm{df}=1$, 21; $\mathrm{p}=0.31$; Fig. 6) on CORT. There was an effect of photoresponsiveness on CORT $(\mathrm{F}=9.39 ; \mathrm{df}=2,24 ; \mathrm{p}<0.001 ;$ Fig. 6$)$ and an effect of time (before vs. after restraint) on CORT $(\mathrm{F}=128.53 ; \mathrm{df}=1,24 ; \mathrm{P}<0.001 ;$ Fig. 6$)$. There was not an interaction between photoperiod and time $(\mathrm{F}=1.62 ; \mathrm{df}=2,24 ; \mathrm{p}=0.22 ;$ Fig. 6$)$. Overall, photostimulated birds had higher CORT than photorefractory ( $\mathrm{p}=0.013$; Fig. 6$)$ and photosensitive $(\mathrm{p}=0.0076$;

Fig. 6) birds. There was not a difference in CORT between photorefractory and photosensitive birds $(\mathrm{p}=0.702$; Fig. 6). Plasma CORT increased after restraint in all photoperiods ( $\mathrm{p}=0.00015$; Fig. 6). Baseline (before restraint) values were not different 
between photoperiods (photostimulated and photorefractory $\mathrm{p}=0.39$; photostimulated and photosensitive $\mathrm{p}=0.19$; photorefractory and photostimulated $\mathrm{p}=0.97$; Fig. 6 ).

There was an effect of photoresponsiveness on plasma $\mathrm{T}(\mathrm{F}=12.07$; $\mathrm{df}=2,13$; $\mathrm{p}=0.001$; Fig. 7), but there was not an overall effect of time (before vs. after restraint) on plasma $\mathrm{T}(\mathrm{F}=2.61 ; \mathrm{df}=1,13 ; \mathrm{p}=0.13$; Fig. 7$)$. There was not an interaction between photoperiod and time $(\mathrm{F}=3.05 ; \mathrm{df}=2,13 ; \mathrm{p}=0.082 ;$ Fig. 7$)$. Plasma $\mathrm{T}$ was higher during the photostimulated period than during photorefractory ( $\mathrm{p}=0.0017$; Fig. 7) and photosensitive ( $\mathrm{p}=0.034$; Fig. 7) periods. There was no difference in plasma $\mathrm{T}$ between photorefractory and photosensitive periods ( $\mathrm{p}=0.94$; Fig. 7). During photostimulation, there was an effect of time (before vs. after restraint) on plasma $\mathrm{T}(\mathrm{t}=3.009 ; \mathrm{df}=5$; $\mathrm{p}=0.029$; Fig. 7). Baseline (before restraint) plasma $\mathrm{T}$ was higher in photostimulated birds than photorefractory $(\mathrm{p}=0.0065)$ and photosensitive $(\mathrm{p}=0.019)$ birds (Fig. 7). Baseline $\mathrm{T}$ was not different between photorefractory and photosensitive birds ( $\mathrm{p}=0.98$; Fig. 7).

There was an effect of photoresponsiveness on plasma $E_{2}(F=18.86 ; \mathrm{df}=2,8$; $\mathrm{p}=0.0009$; Fig. 8), but there was not an effect of time (before vs. after restraint) on plasma $\mathrm{E}_{2}(\mathrm{~F}=0.19 ; \mathrm{df}=1,8 ; \mathrm{p}=0.67 ;$ Fig. 8$)$. There was not an interaction between photoperiod and time $\left(\mathrm{F}=2.75 ; \mathrm{df}=2,8 ; \mathrm{p}=0.12 ;\right.$ Fig. 8). Plasma $\mathrm{E}_{2}$ was higher during the photostimulated period than during the photorefractory period ( $\mathrm{p}=0.0028$; Fig. 8 ) but not the photosensitive period $\left(\mathrm{p}=0.37\right.$; Fig. 8). Plasma $\mathrm{E}_{2}$ was higher during the photosensitive period than the photorefractory period $(\mathrm{p}=0.012$; Fig. 8). Although there was an effect of photoresponsiveness on plasma $\mathrm{E}_{2}$, baseline (before restraint) values were not different between photoperiods (photostimulated and photorefractory $\mathrm{p}=0.11$; 
photostimulated and photosensitive $\mathrm{p}=0.29$; photorefractory and photostimulated $\mathrm{p}=0.90$; Fig. 8).

\section{Discussion}

\subsection{Hormonal profiles and body condition}

We expected males to have high plasma $\mathrm{T}$ during the breeding season compared to other times of the year, as a result of the HPG axis (see review: Wingfield and Sapolsky, 2003). Plasma T has been shown to increase at the onset of breeding and aid in SCR neuroplasticity, testicular development, and breeding behavior, such as singing (Nottebohm, 1980; Brenowitz et al., 1991; Rasika et al., 1994; Gulledge and Deviche, 1997; Gulledge and Deviche, 1998; Smith et al., 1997a; Dloniak and Deviche, 2001; Sartor et al., 2005; Strand and Deviche, 2007). In monogamous bird species, such as Dark-eyed Juncos and House Finches, $\mathrm{T}$ declines soon after pair formation, possibly because $\mathrm{T}$ is costly to make, decreases paternal behavior, increases aggression (and therefore exposure), and decreases immunity (Hegner and Wingfield, 1987; Wingfield et al., 1990; Ketterson et al., 1992; Casto et al., 2001). In polygynous bird species, however, T remains high for a longer period of time (Wingfield et al., 1990).

Male House Finches are monogamous, thus we expected $\mathrm{T}$ to increase during pair formation, shortly before breeding (pre-breeding, February-March) and begin to decrease soon after, depending on number of clutches. In our population of House Finches, date 
affected baseline T, but season only affected baseline $\mathrm{T}$ in 2010 (construct of seasonal dates outlined in Table 2). There may have been more variation in hormones between birds in 2009 than 2010 (Fig. 1), which may explain why season was only found to affect $\mathrm{T}$ in 2010. Plasma $\mathrm{T}$ was higher during breeding than molt in 2010 (Fig. 1), which is what we expected. Elevated $\mathrm{T}$ induces copulatory behaviors in male songbirds (Wingfield, 1984a); it may be beneficial for male House Finches to maintain elevated plasma $\mathrm{T}$ throughout breeding because House Finch pairs will lay multiple clutches during one breeding season. Also, higher T may be beneficial for some male House Finches who have extra pair copulations within a single breeding season (observational data; common for monogamous birds, Ball and Balthazart, 2002). After July, the end of breeding season, plasma $\mathrm{T}$ decreased in male House Finches and remained low until the next breeding period (Fig. 1). Plasma T does not remain high in non-breeding months because secreting T, maintaining enlarged SCRs, and extensive singing are no longer needed and could be costly to uphold.

During spring, the male songbirds' $\mathrm{CP}$ and testes are typically enlarged (Wolfson, 1954; Wingfield and Farner, 1978, 1979; Wingfield and Sapolsky, 2003). An enlarged CP is important for reproductive success because $\mathrm{CP}$ size and sperm count are positively correlated in male passerine birds (Birkhead et al., 1993; Tuttle et al., 1996). The growth of the $\mathrm{CP}$ is controlled by the HPG axis. In short, GnRH is released from the hypothalamus during photostimulation and causes the release of FSH and LH from the adenohypophysis. In males, FSH stimulates spermatogenesis, which correlates with the enlargement of the testes and $\mathrm{CP}$, while $\mathrm{LH}$ stimulates the testes to produce $\mathrm{T}$. We 
expected the $\mathrm{CP}$ of male House Finches to have a larger diameter during the spring, when $\mathrm{T}$ is high, than at other times of the year. CPs were larger during breeding than prebreeding in both 2009 and 2010, meeting the expectation that CPs enlarge during spring, when plasma $\mathrm{T}$ is high (Fig. 3).

We predicted female House Finches would have high plasma $E_{2}$ during the breeding season compared to other times of the year because female breeding hormones - LH and FSH, followed by $\mathrm{E}_{2}$ - increase before the breeding season for follicle development (due to the HPG axis; see review: Wingfield and Sapolsky, 2003). Plasma $\mathrm{E}_{2}$ levels were not affected by date from 2009 through 2010; we think this is because there was high variation in hormone levels during 2009 and not a strong peak in $\mathrm{E}_{2}$ during the spring of 2010 (Fig. 2). Females were not recaptured in enough seasons during 2009 to analyze $E_{2}$ via a repeated measures analysis. Plasma $E_{2}$ was probably higher during the breeding months in 2009 than at other times of the year (Fig. 2), but high variation between birds limited the statistical significance of those values. Plasma $\mathrm{E}_{2}$ in 2010 was low throughout the year, never peaking during the breeding months (Fig. 2). Some observations may explain this finding. First, males sang shorter songs in 2010 (unpublished data), which may have limited the auditory stimulation female songbirds require for the $\mathrm{LH}, \mathrm{FSH}$, and/or $\mathrm{E}_{2}$ hormonal control (via the HPG axis) of nest building, mounting a copulation solicitation display, follicular development, and egg laying (Kroodsma, 1976; Searcy and Marler, 1981; Vallet and Kreutzer, 1995; Bentley et al., 2000; Leitner and Catchpole, 2002; Maney et al., 2003; also see review: Searcy and Andersson, 1986). Second, 2010 was a colder year than 2009 (personal observation), 
which may have decreased House Finch activity. If female exposure to males' visual and auditory stimulation was limited because of decreased activity, the aforementioned breeding behaviors and hormones, including $\mathrm{E}_{2}$, may have been further limited (Polikarpova, 1940; Burger, 1942; Erickson and Lehrman, 1964; Lott and Brody, 1966). Surprisingly, there was an effect of season on plasma $E_{2}$ in 2010; however, any differences between seasons were undetectable via a HSD test. Any effect of season on plasma $E_{2}$ in 2010 may be without importance due to the lack of any notable or large fluctuation throughout the year.

\subsection{Seasonal HVC neuroplasticity}

The enlargement of the HVC occurs because of photostimulation and the associated increase in plasma T (Nottebohm, 1981; Bernard and Ball, 1997; Smith et al., 1997a; and 1997b; Gulledge and Deviche, 1998; Bentley et al., 1999; Whitfield-Rucker and Cassone, 2000; Dloniak and Deviche, 2001; Tramontin et al., 2001; Caro et al., 2005; Sartor et al., 2005; Strand and Deviche, 2007). In song sparrows, the HVC and RA are enlarged by late February (23rd-26th), before plasma $\mathrm{T}$ is increased and while gonads have enlarged less than $10 \%$ of breeding volume (Tramontin et al., 2001). HVC and RA enlargement also happens before increased $\mathrm{T}$ or gonadal enlargement in Corsican blue tits (Caro et al., 2005). Therefore, we expected the HVC and RA to begin to enlarge by February (we captured on February 7th, 2009; photosensitive; Table 1). The HVC had not significantly enlarged by the photosensitive period (February 7th), but was enlarged by 
the photostimulated period (March 21st; Fig. 4). However, there was no difference between HVC volumes of photostimulated and photosensitive birds, thus supporting the hypothesis that $\mathrm{HVC}$ growth begins during the pre-breeding stage. We predicted the HVC and RA would regress rapidly at the onset of photorefractoriness because $\mathrm{T}$ is low and birds are no longer stimulated by day length during this time. As expected, the HVC had regressed by the photorefractory period (July 18th; Fig. 4).

The RA was also enlarged during the photostimulated period (Fig. 5). However, there was a significant difference between photosensitive and photostimulated birds. The RA typically enlarges a week later than the HVC (Tramontin et al., 2000). This may explain why RA growth was so minimal by early February compared to that of the HVC, whose volume was not significantly different between photosensitive and photostimulated birds. As expected, and like the HVC, the RA had regressed by the photorefractory period (Fig. 5).

\subsection{Restraint stress}

We predicted restraint stress would elicit an increase in CORT because of activation of the HPA axis. Restraint stress, especially placing a bird in a cloth bag, is commonly used as a stressor to induce the activation of the HPA axis in birds (Wingfield et al., 1992; Romero et al., 1997; Romero and Remage-Healey, 2000; Remage-Healey and Romero, 2001; Romero and Reed, 2005; Lynn and Porter, 2008). Therefore, we predicted plasma CORT would increase after birds were restrained in a cloth bag for 30 
minutes. As expected, plasma CORT increased after restraint during all three photoperiods, with no difference between sexes (Fig. 6).

We were also interested in the seasonal stress response. For example, House Sparrows have a higher stress response during the breeding season than at other times of the year (Breuner and Orchinik, 2001; Romero, 2006). Other birds with an increased stress response during breeding include the male and female White-crowned Sparrow (Romero et al., 1997; Romero and Wingfield, 1998), male and female Lapland Longspur (Romero et al., 1998b), male and female Snow Bunting (Romero et al., 1998a), male and female Redpolls (Wingfield et al., 1994; Romero et al., 1998c), female Western Sandpiper (O’Reilly, 1995), and male Bush Warbler (Wada et al., 1999). However, our population of House Finches did not differ in their stress response between photostimulated, photorefractory, and photosensitive periods (Fig. 6). This compares to the Black-throated Sparrow, a bird that does not have an increased stress response during breeding (Wingfield et al., 1992). The Black-throated Sparrow lives in the desert, and its restricted stress response may help prevent the delay of breeding during the bird's limited breeding opportunity (Morton, 1976; Wingfield et al., 1992; Breuner et al., 2003). Our population of House Finches doesn't live in a comparable harsh environment, thus we were surprised by the lack of an increased stress response during breeding.

We also predicted that our population of House Finches would have higher baseline CORT concentrations during breeding because many bird species have higher baseline CORT levels during breeding. Bird species with higher breeding CORT concentrations include the male and female White-crowned Sparrow (Wingfield and 
Farner, 1978; Wingfield et al., 1982; Romero et al., 1997; Romero and Wingfield, 1998; Romero and Wingfield, 1999), male and female Song Sparrow (Wingfield, 1984b; Wingfield, 1985a,b; Elekonich and Wingfield, 2000), male and female House Sparrow (Breuner and Orchinik, 2001), male Dark-eyed junco (Deviche et al., 2000), male and female Lapland Longspur (Romero et al., 1998b), male and female Snow Bunting (Romero et al., 1998a), male Red-winged Blackbird (Johnsen, 1998), male Brownheaded Cowbird (Dufty and Wingfield, 1986), male and female Redpolls (Romero et al., 1998c), and male Greylag Goose (Kotrschal et al., 1998). Plasma CORT increases during stressful conditions, enabling the release of stored energy, a potential benefit for breeding. As expected, photostimulated House Finches had higher CORT than photosensitive and photorefractory birds (Fig. 6). Although CORT was higher in photostimulated birds, there was no seasonal difference in baseline (before restraint) levels. Because there was no seasonal difference in baseline CORT or a seasonal difference in stress response, the difference in CORT between photoperiods is due to an overall increase in CORT (before and after restraint).

The elevated levels of CORT during the breeding season correspond to the high breeding concentrations of plasma $\mathrm{T}$ in males. As expected, baseline plasma $\mathrm{T}$ was higher in photostimulated (breeding) birds than photorefractory and photosensitive birds (Fig. 7). Baseline $\mathrm{T}$ was not different between photorefractory and photosensitive birds, indicating that baseline $\mathrm{T}$ is high during the breeding season and low at other times of the year. Plasma $\mathrm{T}$ is needed for males' reproductive success, and interestingly, high CORT has been shown to decrease T (Dong et al., 2004; Hardy et al., 2005; Deviche et al., 2010; 
also see review: Wingfield and Sapolsky, 2003). In short, CORT reduces gonadal receptivity to LH, which decreases T production (review: Wingfield and Sapolsky, 2003). Stress can also decrease T through CORT-independent mechanisms. Within seconds after a stressor, beta-endorphin reduces $\mathrm{GnRH}$ secretion from the hypothalamus, which decreases FSH and LH secretions from the adenohypophysis (review: Wingfield and Sapolsky, 2003). Because LH stimulates $\mathrm{T}$ production, plasma $\mathrm{T}$ concentrations also decrease. Both of these CORT-dependent and -independent mechanisms rely on a decrease in LH or a decrease in gonadal receptivity to LH. Interestingly, there may be a third mechanism by which stress decreases plasma $\mathrm{T}$ - by directly inhibiting the testes' ability to produce $\mathrm{T}$ (Deviche at al., 2010). In our population of wild house finches, $\mathrm{T}$ decreased in photostimulated males after they were restrained (Fig. 7). We predicted photosensitive and photorefractory $\mathrm{T}$ levels would be too low to allow us to detect an appreciable decrease in $\mathrm{T}$ from the presence of CORT because $\mathrm{T}$ is very low during nonbreeding times of the year (determined by 2009 hormonal profile data). Plasma T was not affected by restraint in photosensitive or photorefractory males. This further illustrates that male House Finches are sensitive to stress during the breeding season, which may benefit them by postponing the hatching of young during low food or bad weather environments. Birds with short breeding seasons would not be as benefited.

We thought CORT would decrease $\mathrm{E}_{2}$ in female House Finches because CORT decreases $\mathrm{GnRH}$ and $\mathrm{LH}$, which should also decrease $\mathrm{E}_{2}$ secretion; this has been shown in other female animals, such as mammals (see review: Wingfield and Sapolsky, 2003). In one study on White-crowned Sparrows, stress did not decrease females' estrogen 
during breeding (Wingfield et al., 1982). However, most songbird stress research focuses on CORT alone or in conjunction with $\mathrm{T}$, not $\mathrm{E}_{2}$. Restraint stress and/or CORT did not affect plasma $E_{2}$ in any photoperiod (Fig. 8). The restraint stress protocol was carried out in 2010, when the $\mathrm{E}_{2}$ hormonal profile was not as expected (Fig. 2; see 4.1 Hormonal profiles, above). Had the stress experiment been performed in 2009, when $\mathrm{E}_{2}$ appeared to increase during spring, we might have seen a decrease in $\mathrm{E}_{2}$ after restraint-stress. Conversely, stress may have a greater impact on plasma $T$ than on plasma $E_{2}$ in House Finches, and this may be why there is little published research on the effect of stress and/ or CORT on $\mathrm{E}_{2}$ in songbirds. More studies need to be done on the effects of stress on female songbirds, especially during the photostimulated period.

Interestingly, both photosensitive and photostimulated females had higher $\mathrm{E}_{2}$ than photorefractory females (Fig. 8). Although photosensitive and photostimulated birds had higher $\mathrm{E}_{2}$ levels, there was not a difference in baseline values between any photoperiod. Because there was no seasonal difference in baseline $\mathrm{E}_{2}$ or a seasonal difference in stress response, the difference in $E_{2}$ between photoperiods is due to an overall increase in $E_{2}$ (before and after restraint). We expected baseline $\mathrm{E}_{2}$ to be higher during photostimulation/breeding, as seen in other songbirds (via the HPG axis; see review: Wingfield and Sapolsky, 2003). There may be an explanation for why we did not see a high baseline $\mathrm{E}_{2}$ level during spring. During the restraint-stress experiment, we had a limited sample size for photorefractory $(\mathrm{n}=2)$ and photosensitive $(\mathrm{n}=3)$ periods compared to the photostimulated period ( $\mathrm{n}=7$ ), causing high variation (Fig. 8). Second, the restraintstress protocol was carried out in 2010, when $\mathrm{E}_{2}$ did not peak (Fig. 2; see 4.1 Hormonal 
profiles, above). This may have occurred because of a lack of auditory and/or visual stimulus from male House Finches (see 4.1 Hormonal profiles, above). Had the restraintstress experiment been carried out in 2009 , we may have seen a higher baseline $\mathrm{E}_{2}$ level during photostimulation in addition to the overall increased plasma $E_{2}$ level that we did see in photostimulated and photosensitive females.

\subsection{Conclusions}

Hormonal profiles differ year to year, possibly due to extenuating factors such as weather or food availability. Females may be more prone to variations in their hormonal profiles because they may rely upon auditory and visual stimulation from males. The seasonal neuroplasticity of House Finch SCRs follow that of other songbirds, being enlarged during breeding, when plasma $\mathrm{T}$ is high, and diminished in size at the onset of photorefractoriness, when plasma $\mathrm{T}$ decreases.

Furthermore, our research suggests that stress is detrimental to male House Finches during photostimulation (breeding) because CORT is higher and stress decreases plasma $\mathrm{T}$ at this time. Decreased plasma $\mathrm{T}$ may be detrimental to male songbirds' breeding success because plasma $\mathrm{T}$ is important for singing and copulatory behavior (Wingfield, 1984a; Smith et al., 1997a; Gulledge and Deviche, 1998; Dloniak and Deviche, 2001; Sartor et al., 2005; Strand et al., 2008). Plasma T is also important for enhancing House Finch SCR growth during photosensitivity (Strand and Deviche, 2007), 
thus stress may also limit neuroplasticity (see Ch. 2 for further study). We recommend more studies be done on the effects of stress on female songbirds. 


\section{Tables}

Table 1. Photoperiods and their associated dates, as determined for our field site during 2009 and 2010.

\begin{tabular}{|c|c|}
\hline Month & Photoperiod \\
\hline February - July & Photostimulated \\
\hline July- November & Photorefractory \\
\hline November - February & Photosensitive \\
\hline
\end{tabular}

Table 2. Breeding periods and their associated dates, as determined for our field site during 2009 and 2010. The end of pre-breeding and beginning of breeding was determined when nest building commenced (early/mid-March) and captured female House Finches had brood patches (mid-March, April); the end of breeding and beginning of molt was determined when captured House Finches showed signs of molt; the end of molt and beginning of non-breeding was determined when captured House Finches no longer showed signs of molt; the end of non-breeding and beginning of pre-breeding was determined when day length began to increase.

\begin{tabular}{|c|c|}
\hline Date & Breeding Period \\
\hline January 1 - March 15 & Pre-breeding \\
\hline March 16 - July 23 & Breeding \\
\hline July 24 - October 15 & Molt \\
\hline October 16 - December 31 & Non-breeding \\
\hline
\end{tabular}


Table 3. Sample sizes of hormone data from wild House Finches. Sample size (n): number of blood samples taken from wild House Finches for hormone profile analyses (corresponds with Figures 1 and 2). Repeated Measures sample size (R.M. n): resulting sample sizes of House Finch hormone data after values were deleted for the purpose of analyzing the data via repeated measures ANOVA (corresponds with Table 4). No bird was recaptured every season. In order to run a repeated measures ANOVA, values of birds not caught in at least two different seasons within the same year were deleted.

\begin{tabular}{|c|c|c|c|c|c|c|c|}
\hline \multicolumn{4}{|c|}{ MALES, T } & \multicolumn{4}{|c|}{ FEMALES, $E_{2}$} \\
\hline Season & Year & $\mathbf{n}$ & R.M. n & Season & Year & $\mathbf{n}$ & R.M. $n$ \\
\hline \multirow{2}{*}{$\begin{array}{l}\text { Pre-breeding } \\
\text { (Jan. } 1 \text { - Mar. 15) }\end{array}$} & 2009 & 16 & 4 & \multirow{2}{*}{$\begin{array}{c}\text { Pre-breeding } \\
\text { (Jan. } 1 \text { - Mar. 15) }\end{array}$} & 2009 & 4 & 2 \\
\hline & 2010 & 25 & 12 & & 2010 & 20 & 11 \\
\hline \multirow{2}{*}{$\begin{array}{c}\text { Breeding } \\
\text { (Mar. } 16 \text { - July 23) }\end{array}$} & 2009 & 40 & 7 & \multirow{2}{*}{$\begin{array}{c}\text { Breeding } \\
\text { (Mar. } 16 \text { - July 23) }\end{array}$} & 2009 & 30 & 6 \\
\hline & 2010 & 38 & 16 & & 2010 & 26 & 13 \\
\hline \multirow{2}{*}{$\begin{array}{c}\text { Molt } \\
\text { (July } 24 \text { - Oct. 15) }\end{array}$} & 2009 & 14 & 4 & \multirow{2}{*}{$\begin{array}{c}\text { Molt } \\
\text { (July } 24 \text { - Oct. 15) }\end{array}$} & 2009 & 13 & 9 \\
\hline & 2010 & 22 & 14 & & 2010 & 6 & 4 \\
\hline \multirow{2}{*}{$\begin{array}{l}\text { Non-breeding } \\
\text { (Oct. } 16 \text { - Dec. 31) }\end{array}$} & 2009 & 17 & 8 & \multirow{2}{*}{$\begin{array}{c}\text { Non-breeding } \\
\text { (Oct. } 16 \text { - Dec. 31) }\end{array}$} & 2009 & 24 & 7 \\
\hline & 2010 & 13 & 1 & & 2010 & 8 & 1 \\
\hline
\end{tabular}


Table 4. Statistical tests and results. Due to lack of repeated captures, the repeated measures ANOVA analyses could not be performed on all data:

Plasma T, 2009 — repeated measures ANOVA did not include pre-breeding data.

Plasma T, 2010 - repeated measures ANOVA did not include non-breeding data.

Plasma $E_{2}, 2009$ - not enough recaptures to perform a repeated measures ANOVA.

Plasma $\mathrm{E}_{2}, 2010$ - repeated measures ANOVA did not include non-breeding data.

CP diameter, 2009 - repeated measures ANOVA could not be performed on all seasons in one analysis. $\uparrow$ did not include molt data. $†+$ did not include pre-breeding data. CP diameter, 2010 - repeated measures ANOVA did not include non-breeding data.

\begin{tabular}{|c|c|c|c|}
\hline & $\mathbf{F}$ & df & $\mathbf{p}$ \\
\hline \multicolumn{4}{|l|}{ Plasma $T(\log (10)$ transformed $)$} \\
\hline one-way ANOVA by sampling date, $2009-10$ & 3.18 & 40,52 & $<0.0001$ \\
\hline repeated measures ANOVA by season, 2009 & 64.54 & 1,1 & 0.079 \\
\hline repeated measures ANOVA by season, 2010 & 104.31 & 1,6 & $<0.0001$ \\
\hline \multicolumn{4}{|l|}{ Plasma $\mathbf{E}_{2}$} \\
\hline one-way ANOVA by sampling date, $2009-10$ & 1.47 & 37,17 & 0.19 \\
\hline repeated measures ANOVA by season, 2009 & $\mathrm{x}$ & $\mathrm{x}$ & $\mathrm{x}$ \\
\hline repeated measures ANOVA by season, 2010 & 171.94 & 1,2 & $<\mathbf{0 . 0 1}$ \\
\hline \multicolumn{4}{|l|}{ CP diameter } \\
\hline one-way ANOVA by sampling date, 2009-10 & 8.58 & 40,59 & $<0.0001$ \\
\hline repeated measures ANOVA by season, $2009^{\dagger}$ & 700.20 & 1,4 & $<0.0001$ \\
\hline repeated measures ANOVA by season, $2009^{t+}$ & 491.50 & 1,2 & $<0.001$ \\
\hline repeated measures ANOVA by season, 2010 & 1747.41 & 1,8 & $<0.00001$ \\
\hline
\end{tabular}




\section{Figures}

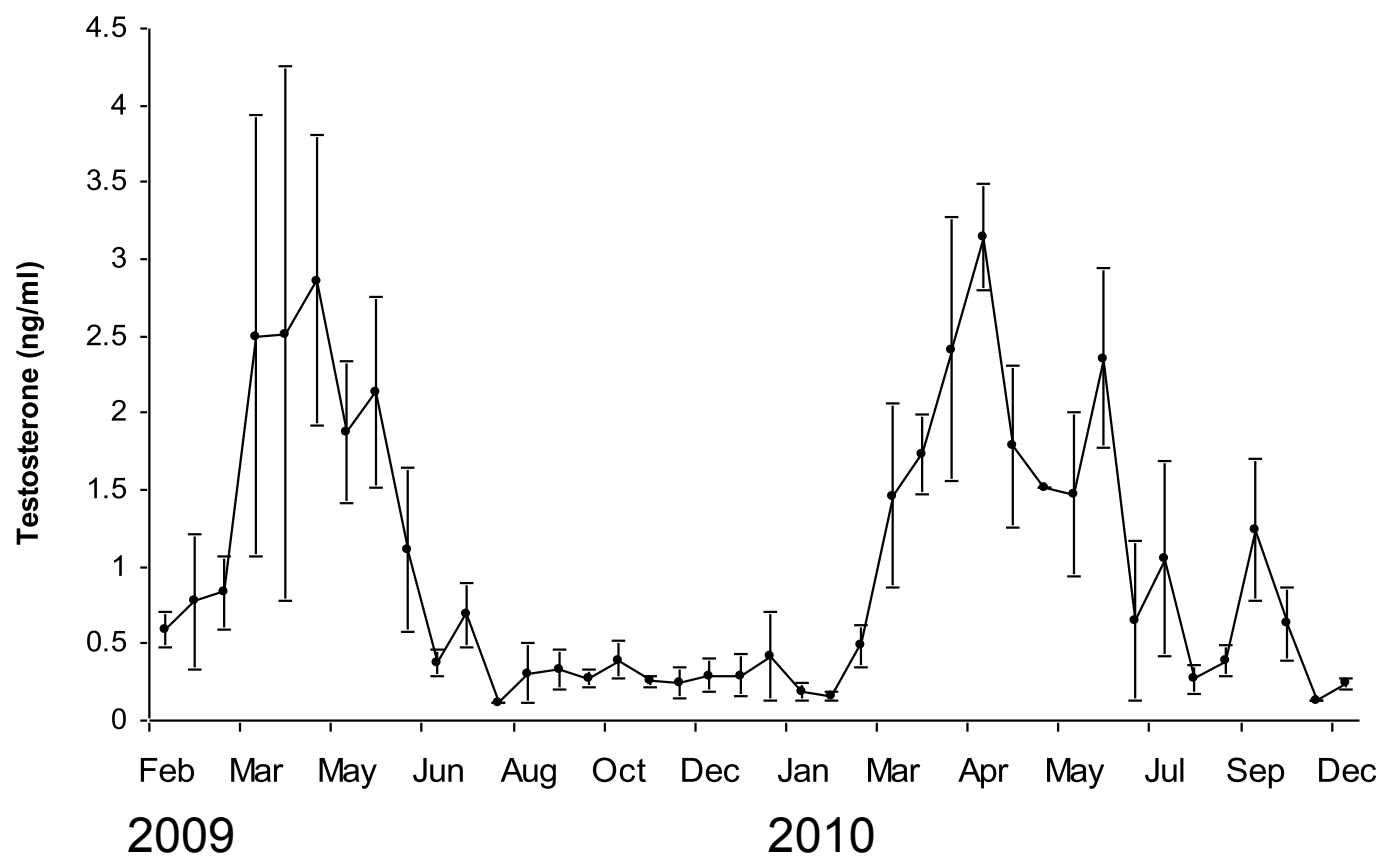

Figure 1. Seasonal profile of testosterone ( $\mathrm{ng} / \mathrm{ml}$; mean $+/-\mathrm{se})$ of male House Finches from February 2009 to January 2011 ( $n=2-9 /$ sample). See Table 3 for sample sizes (n). 


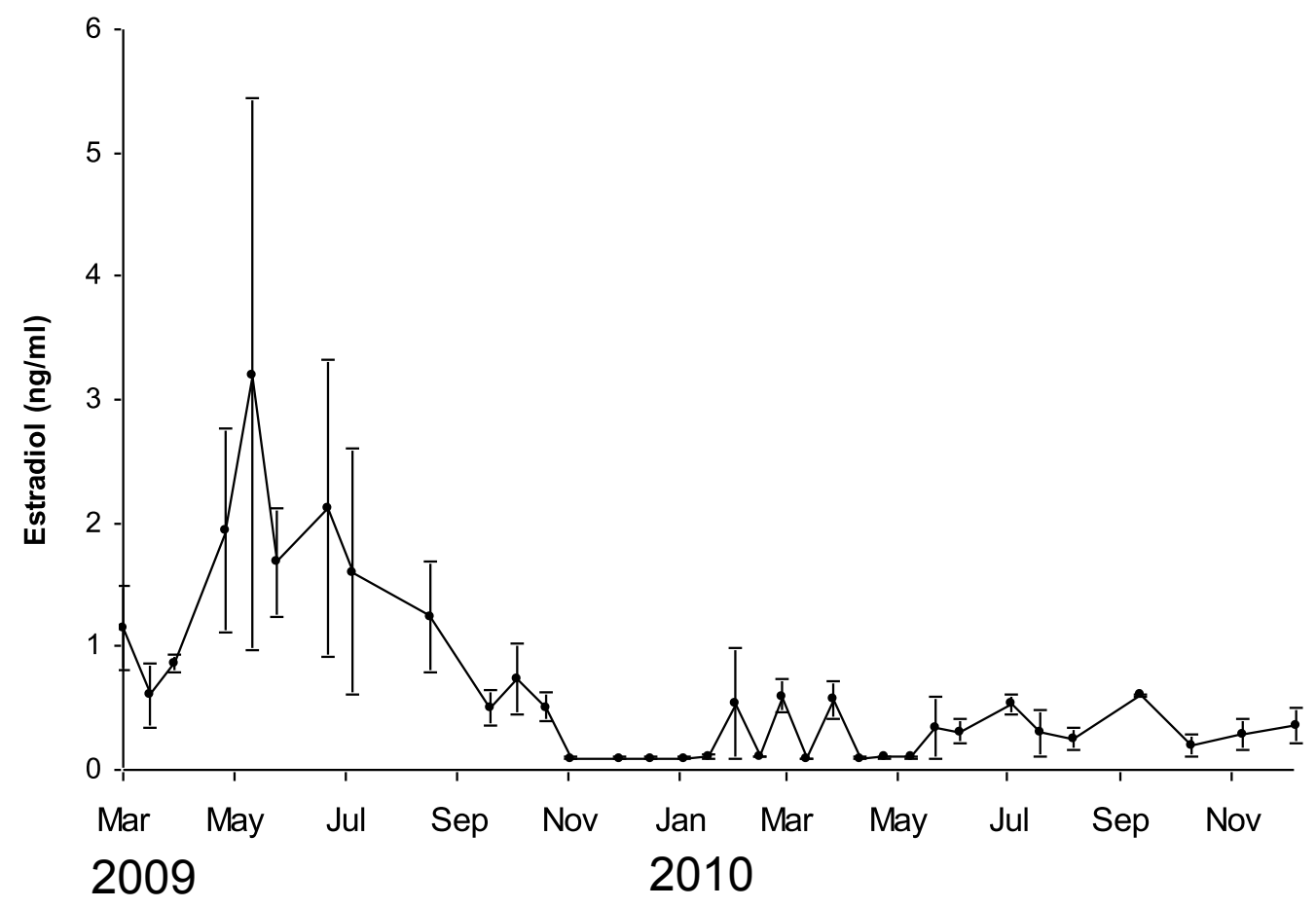

Figure 2. Seasonal profile of estradiol (ng/ml; mean $+/-\mathrm{se})$ of female House Finches from March 2009 to January 2011 (n=2-8/sample). See Table 3 for sample sizes (n).

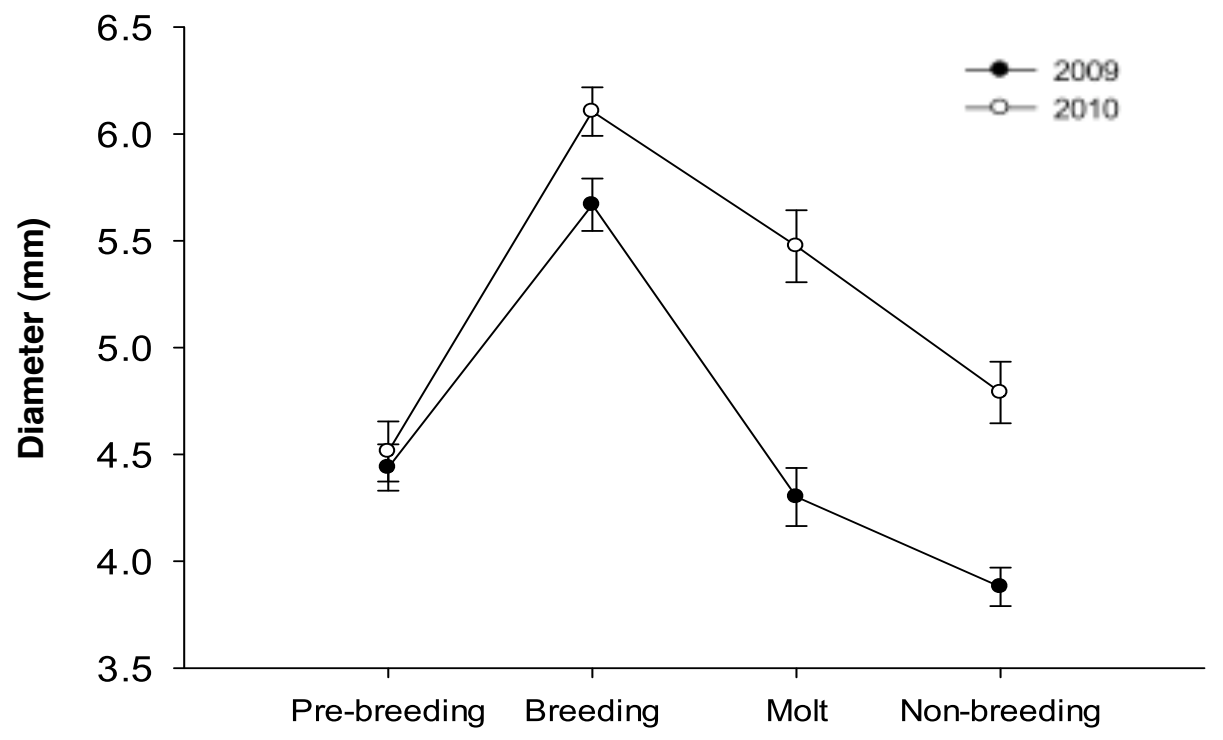

Figure 3. Cloacal protuberance diameter $(\mathrm{mm})$ of male House Finches from January 2009 to December 2010. 


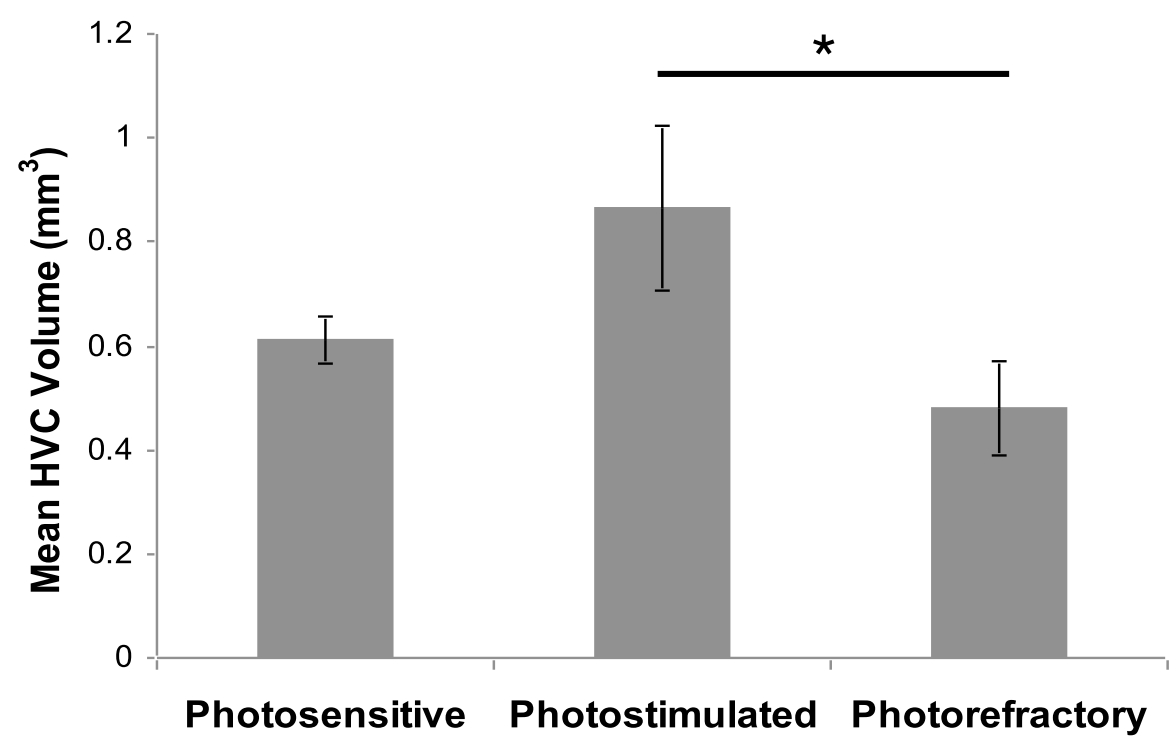

Figure 4. HVC volumes $\left(\mathrm{mm}^{3}\right.$, mean $\left.+/-\mathrm{se}\right)$ from male House Finches on February 7 th (photosensitive), March 21st (photostimulated), and July 18th (photorefractory) of 2009. Photostimulated birds had a significantly larger HVC than photorefractory birds $(p=0.038)$.

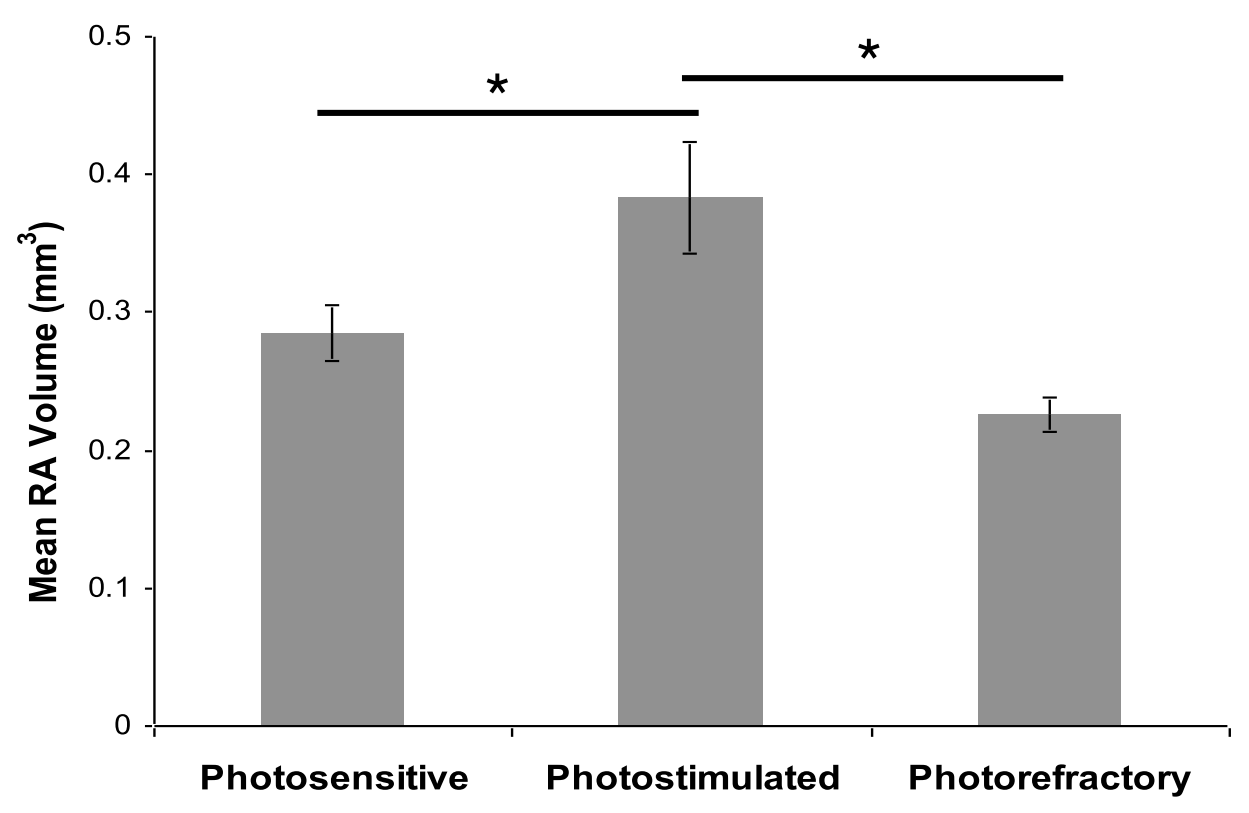

Figure 5. RA volumes $\left(\mathrm{mm}^{3}\right.$, mean $\left.+/-\mathrm{se}\right)$ from male House Finches on February 7th (photosensitive), March 21st (photostimulated), and July 18th (photorefractory) of 2009. Photostimulated birds had a significantly larger RA than photorefractory $(p=0.0026)$ and photosensitive $(\mathrm{p}=0.049)$ birds. 


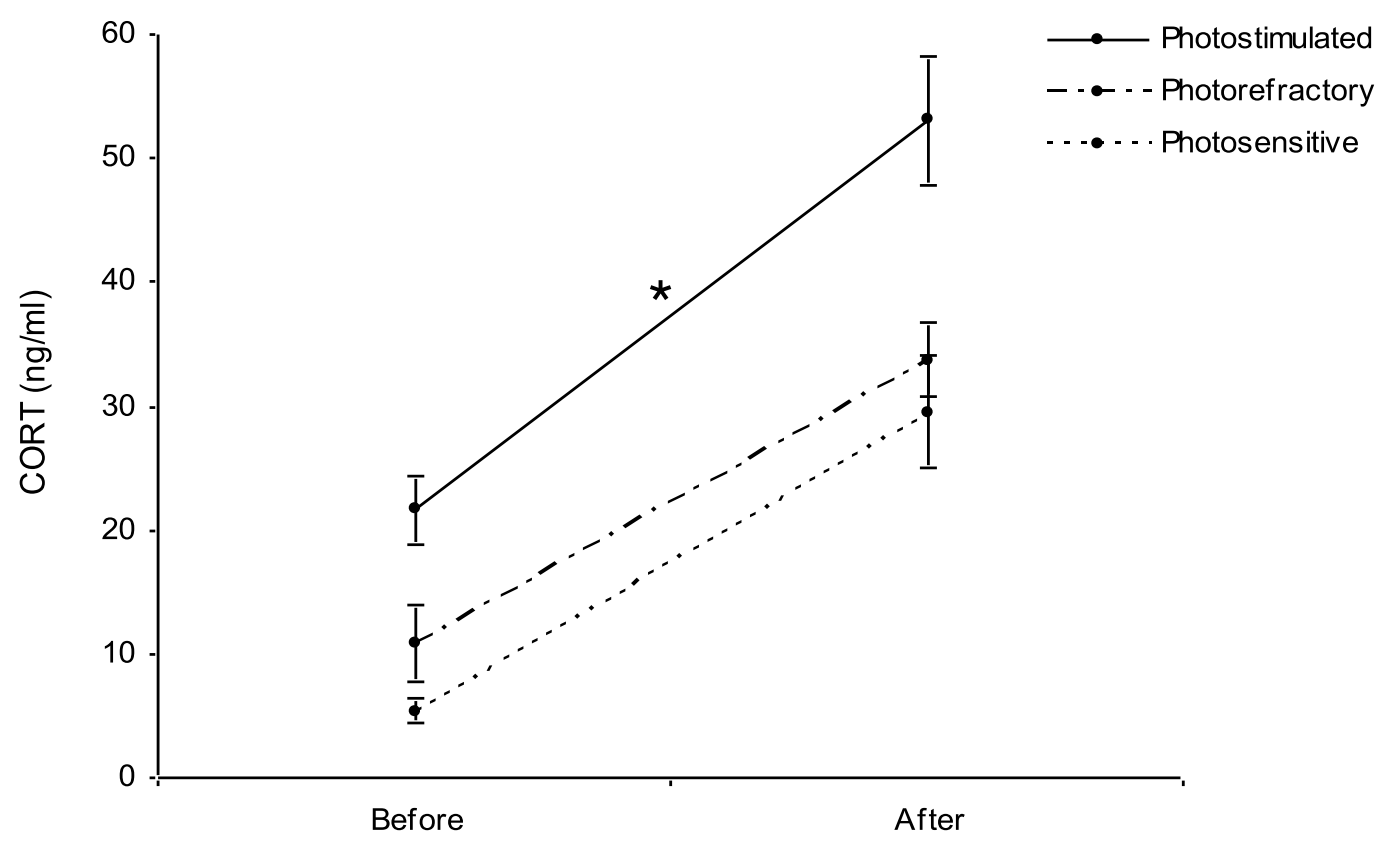

Figure 6. Plasma CORT concentrations ( $\mathrm{ng} / \mathrm{ml}$; mean $+/-\mathrm{se}$ ) from male and female House Finches before and after they were restrained in a bag for 30 minutes. There is not an effect of gender. Photostimulated samples were taken on March 4 (pre-breeding) and April 2 (breeding); photorefractory samples were taken on August 12 and 13 (molt); photosensitive samples were taken on December 12 (non-breeding). All samples were from the year 2010. Plasma CORT was significantly higher in photostimulated birds than photorefractory $(\mathrm{p}=0.013)$ and photosensitive $(\mathrm{p}=0.0076)$ birds. 


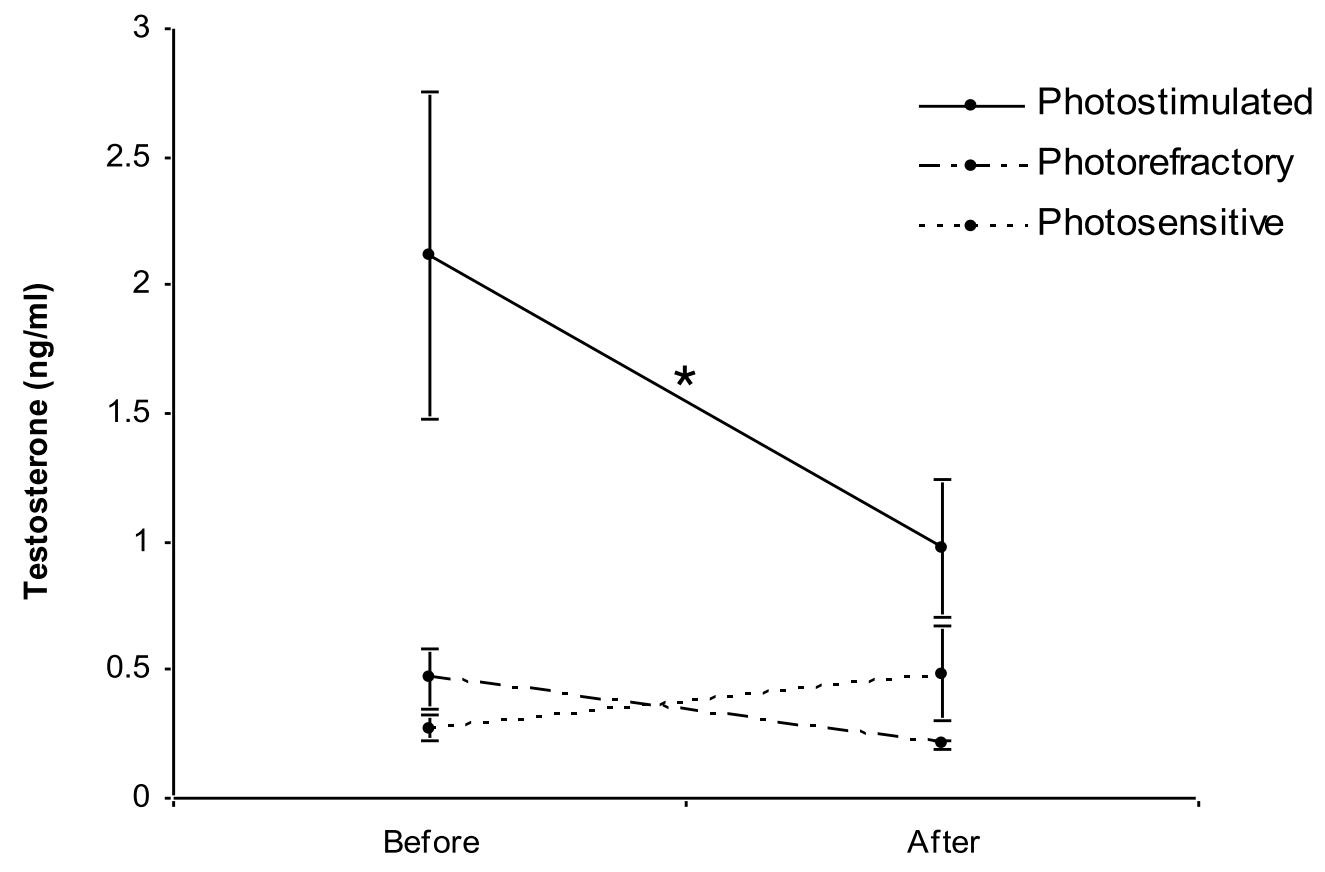

Figure 7. Plasma $\mathrm{T}$ concentrations ( $\mathrm{ng} / \mathrm{ml}$; mean $+/$ - se) from male House Finches before and after they were restrained in a bag for 30 minutes. Photostimulated samples were taken on March 4 (pre-breeding) and April 2 (breeding); photorefractory samples were taken on August 12 and 13 (molt); photosensitive samples were taken on December 12 (non-breeding). All samples were from the year 2010. Plasma T was significantly higher in photostimulated birds than photorefractory $(\mathrm{p}=0.0017)$ and photosensitive $(\mathrm{p}=0.034)$ birds. 


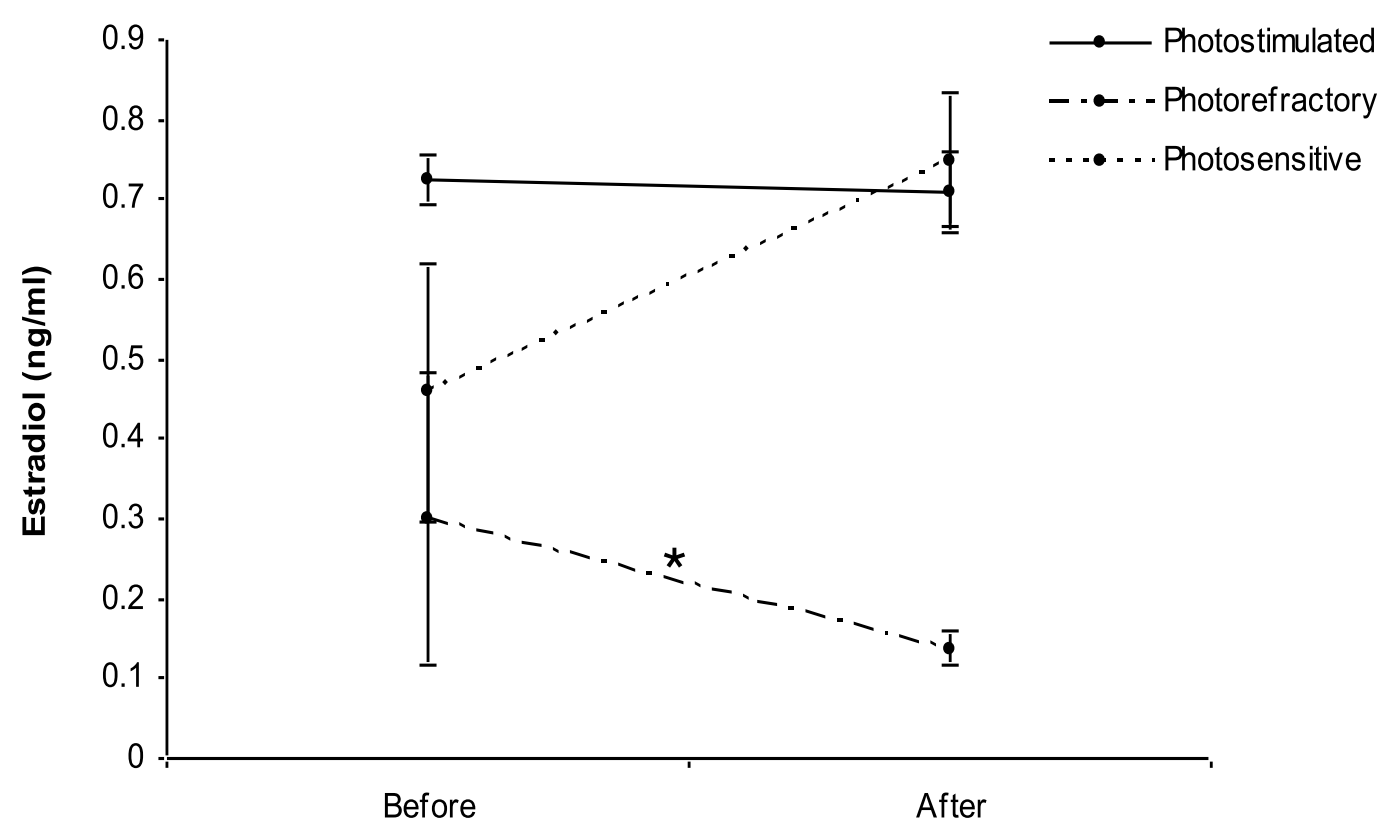

Figure 8. Plasma $E_{2}$ concentrations ( $\mathrm{ng} / \mathrm{ml}$; mean $\left.+/-\mathrm{se}\right)$ from female House Finches before and after they were restrained in a bag for 30 minutes. Photostimulated samples were taken on March 4 (pre-breeding) and April 2 (breeding); photorefractory samples were taken on August 12 and 13 (molt); photosensitive samples were taken on December 12 (non-breeding). All samples were from the year 2010. Plasma $\mathrm{E}_{2}$ was significantly lower in photorefractory birds than both photosensitive $(\mathrm{p}=0.012)$ and photostimulated $(\mathrm{p}=0.0028)$ birds. 


\section{II.}

\section{Stress affects song control nuclei growth in adult male House Finches, Carpodacus mexicanus}

\section{Introduction}

House finches (Carpodacus mexicanus), like other songbirds, sing more during spring than other times of the year to attract a mate and/or maintain pair bonds (Bergtold, 1913; Cox, 1944; Catchpole, 1973; Slagsvold, 1977; Logan, 1983). Specific brain nuclei in songbirds, known as the song control regions (SCRs), are involved with the learning, production, and maintenance of song (Nottebohm, 1981). In the neural descending motor pathway, the HVC (acronym used as common name), a specific SCR that controls song learning and production, projects to the robust nucleus of the arcopallium (RA), a SCR involved in song output (Fig. 1; Nottebohm et al., 1976; Scharff and Nottebohm, 1991). The RA projects to the tracheosyringeal portion of the nucleus of the XII cranial nerve, which controls the musculature for singing via the syrinx (Nottebohm et al., 1976; Scharff and Nottebohm, 1991; also see reviews: Vicario, 1991; Brenowitz and Kroodsma, 1996; Brenowitz et al., 1997; Margoliash, 1997).

Intriguingly, the SCRs of many songbirds undergo an increase in size during the spring, when plasma testosterone (T) is high and song is stable (Nottebohm, 1981; Nottebohm et al., 1987; Kirn et al., 1989; Smith, 1996; Smith et al., 1997a; Smith et al., 1997b), and the SCRs resolve back to their non-breeding state after the breeding season is over (Nottebohm, 1981; Kirn et al., 1989; Smith, 1996; Smith et al., 1997a; Smith et al., 
1997b). Neuroplasticity of SCRs may be due to neurogenesis, increase in cell size, and/or a decrease in the density of neurons (Kirn et al., 1994; Nottebohm, 2002; Strand and Deviche, 2007).

Because singing is typically initiated by male birds (Nottebohm, 1975), male SCRs tend to be larger than females' during the breeding season (Nottebohm, 1980). Male song sparrows and canaries with developed SCRs have greater song stereotypy, or similarity of songs, than those with small SCRs, which tend to have variable song (Nottebohm, 1981; Nottebohm et al., 1986; Smith et al., 1997a). Male House Finches with greater song length procure their first clutch earlier than House Finches with shorter songs, and male House Finches with faster song rates produce larger clutches (Mennill et al., 2006). Because greater song stereotypy, trill performance, song length, song rate, number of song types, and/or number of notes per song may be desired by female songbirds, male songbirds with developed SCRs may gain reproductive success (Kroodsma, 1976; Bentley et al., 2000; Leitner and Catchpole, 2002; Nolan and Hill, 2004; Mennill et al., 2006; Caro et al., 2010; also see reviews: Searcy and Andersson, 1986; Nowicki and Searcy, 2004). Females determine mate quality from song, because it is potentially costly to be singing (attracting competition or predators) and/or because SCRs are costly to develop (Nowicki et al., 1998; also see review: Nowicki and Searcy, 2004). Many factors contribute to the phenomenon of SCR neuroplasticity, including photoperiod (Bernard and Ball, 1997; Smith et al., 1997b; Whitfield-Rucker and Cassone, 2000; Dloniak and Deviche, 2001; also see review: Wilson and Donham, 1988), plasma T concentrations (Nottebohm, 1980; Brenowitz et al., 1991; Rasika et al., 1994; Gulledge 
and Deviche, 1997; Smith et al., 1997a; Sartor et al., 2005; Strand and Deviche, 2007), and the act of singing, or auditory feedback (Nordeen and Nordeen, 1992; Li et al, 2000; Brainard and Doupe, 2000b; Alvarez-Borda and Nottebohm, 2002; Sartor and Ball, 2005; also see review: Brainard and Doupe, 2000a).

During spring, as photoperiod increases (photostimulation), the change in day length activates the hypothalamic-pituitary-gonadal (HPG) axis, by causing the release of gonadotropin releasing hormone $(\mathrm{GnRH})$ from the hypothalamus (see review: Wingfield and Sapolsky, 2003). Higher levels of GnRH increase the production of luteinizing hormone (LH) and follicle stimulating hormone (FSH) from the adenohypophysis (see review: Wingfield and Sapolsky, 2003). Photostimulation, along with increased LH and FSH, ultimately stimulates the growth of the testes in males, resulting in increased concentrations of T (Hamner, 1966; also see review: Wingfield and Sapolsky, 2003). Photostimulation, along with increasing $\mathrm{T}$, initiates a suite of physiological and behavioral responses, including the enlargement of SCRs (Nottebohm, 1981; Bernard and Ball, 1997; Smith et al., 1997a; 1997b; Gulledge and Deviche, 1998; Bentley et al., 1999; Whitfield-Rucker and Cassone, 2000; Dloniak and Deviche, 2001; Tramontin et al., 2001; Caro et al., 2005; Sartor et al., 2005; Strand and Deviche, 2007; also see review: Wilson and Donham, 1988). Nottebohm proposed that when plasma T levels are high, the survival rate of new or existing neurons in the HVC is enhanced (Nottebohm, 2002). This could explain why there are more neurons in songbird SCRs during the breeding season. Alternatively, $\mathrm{T}$ may increase neurogenesis, which would increase the total number of neurons in the HVC. 
There are high levels of neuronal death in the HVC of canaries in the months before the breeding season (January), but when photoperiod increases (March), there are higher levels of neuronal survival and neuronal recruitment (Kirn et al., 1994). This supports Nottebohm's proposal, that high T enhances the survival rate of new neurons in the HVC, but it does not directly test for the effects of T. If given T-treatment, House Finches have increased HVC and RA volumes and increased total number of neurons in the HVC (Strand and Deviche, 2007). However, the total number of new neurons does not change in the HVC, suggesting the T-induced increase in neuronal number is attributed to increased neuron survival (Strand and Deviche, 2007), which also supports Nottebohm's proposal.

Although photoperiod, plasma $\mathrm{T}$, and singing mediate neuroplasticity, another factor that may contribute to SCR growth is stress. Stress causes the release of corticotropin-releasing factor via the hypothalamic-pituitary-adrenal (HPA) axis. This hormone causes the release of adrenocorticotropic hormone (ACTH) from the adenohypophysis, which, in turn, causes the release of the glucocorticoid hormone corticosterone (CORT) from the adrenal cortex (Wingfield et al., 1982; 1983; 1994; 1995; also see reviews: Siegel, 1980; Harvey et al., 1984; Wingfield and Sapolsky, 2003). The effects of stress and/or CORT on neurogenesis have been extensively studied in mammals. CORT decreases cell proliferation in the brains of rats (Cameron and Gould, 1994; Malberg and Duman, 2003; Banasr et al., 2007), and in monkeys, stress decreases neurogenesis in the dentate gyrus (Gould et al., 1998). 
The mechanism by which CORT affects neurogenesis can vary by species. In mammals, neurogenesis is not regulated by plasma $\mathrm{T}$ but is negatively affected by CORT. In songbirds, however, plasma $\mathrm{T}$ is the primary mechanism mediating seasonal neuroplasticity (Nottebohm et al., 1987; Smith et al., 1995; Gulledge and Deviche, 1997; Strand and Deviche, 2007), and high stress and CORT levels decrease plasma $\mathrm{T}$ concentrations (Dong et al., 2004; Hardy et al., 2005; Deviche et al., 2010; also see review: Wingfield and Sapolsky, 2003). Stress may affect T concentrations by decreasing LH secretion, decreasing the sensitivity of the gonads to $\mathrm{LH}$, or directly inhibiting $\mathrm{T}$ production (Wingfield and Sapolsky, 2003; Deviche et al., 2010). This negative interaction between stress and $\mathrm{T}$ concentrations may be a mechanism by which stress limits SCR neuroplasticity.

Various kinds of stress can have adverse effects beyond impacting neurogenesis, such as affecting song quality and body condition. In Swamp Sparrows, early nutritional stress can cause poor copying of songs and cause decreased HVC and RA volumes (Nowicki et al., 2002). Fledgling Song Sparrows also had decreased HVC volumes after this type of stressor (MacDonald et al., 2006). Early nutritional stress suppressed the humoral immune response, lowered body weight, and shortened and delayed songs in European Starlings (Buchanan et al., 2003). Nutritional stress and/or CORT injections reduced nestling growth rates, shortened songs, and reduced HVC volumes in Zebra Finches (Buchanan et al., 2004). We were interested in the effects of stress during adulthood on neuroplasticity, and in many stress studies performed on adult birds, restraint is often used as the stressor. Placing a bird in a cloth bag has been shown to 
induce the stress response in many bird species, including European Starlings (Romero and Remage-Healey, 2000; Remage-Healey and Romero, 2001), House Sparrows (Romero and Reed, 2005; Lynn and Porter, 2008), White-Crowned Sparrows (Romero et al., 1997; Romero and Reed, 2005), Common Redpolls (Romero and Reed, 2005), Snow Buntings (Romero and Reed, 2005), Lapland Longspurs (Romero and Reed, 2005), Albert's Towhees (Wingfield et al., 1992), Inca Doves (Wingfield et al., 1992), BlackThroated Sparrows (Wingfield et al., 1992), Cactus Wrens (Wingfield et al., 1992), and Curve-billed Thrashers (Wingfield et al., 1992). Therefore, restraint stress by use of a cloth bag is often considered a standard stressor to activate the HPA axis response in adult birds.

This study first investigates the $\mathrm{T}$ and CORT hormonal profiles of male House Finches while they are acclimating to captivity. Because of the HPG axis, we expected the birds would have low $\mathrm{T}$ levels while kept on short days, emulating winter, and that $\mathrm{T}$ would increase once birds were switched to long days (spring; photostimulated). We hypothesized that bringing the birds into captivity would affect CORT. We predicted that CORT would initially be high but decrease with time due to the birds' acclimation to the "stress" of captivity. We then investigate how restraint-stress and/or CORT affect the birds' hormonal profiles, neuroplasticity, and neurogenesis during photostimulation. We hypothesized that during photostimulation (spring), stress/CORT would negatively affect plasma T, SCR volumes, and neurogenesis. We predicted that 1) CORT would be increased in restraint-stressed birds, 2) $\mathrm{T}$ would be decreased in restrained birds, 3) 
restraint-stressed birds would have smaller SCR volumes than non-stressed birds, and 4) restrained birds would have reduced SCR neurogenesis compared to non-restrained birds.

\section{Materials and methods}

\subsection{Animals}

We captured 15 adult male House Finches in Santa Margarita, California $(34.953 \mathrm{~N},-120.434 \mathrm{~W})$ between January 23 and February 02, 2010, when days have a short light photoperiod and birds are photosensitive. Birds were driven 19 miles to California Polytechnic State University, San Luis Obispo, placed into individual cages, visually isolated from each other, and kept on short days (8L:16D; lights on at 8:00 AM and off at 4:00 PM) at $25^{\circ} \mathrm{C}$ with food and water available ad libitum.

All procedures were approved by the California Polytechnic State University Institutional Animal Care and Use Committee. Scientific collecting permits were secured from the California Department of Game and Fish and the United States Fish and Wildlife Service before collection.

\subsection{Acclimation}

The morning after each bird was brought into captivity, we collected a $200 \mu \mathrm{l}$ blood sample via alar vein puncture and collected into microhematocrit tubes. Blood 
samples were centrifuged and plasma was collected and stored at $-20^{\circ} \mathrm{C}$. The birds were allowed to acclimate to $8 \mathrm{~L}: 16 \mathrm{D}$ lab conditions for four weeks; blood samples were taken each week, beginning the day after capture. All samples were taken each day at 10:00 AM to eliminate effects of daily hormone cycles. Samples were centrifuged and plasma was collected and stored at $-20^{\circ} \mathrm{C}$ until measured for $\mathrm{T}$ and CORT concentrations.

\subsection{Restraint stress experiment}

After the acclimation period, all birds were photoshifted to long days (16L:8D; lights on at 6:00 AM and off at 10:00 PM), typical of their breeding conditions, and were randomly divided into two groups. The restraint group was restrained in cloth bags for thirty minutes, at 11:00 AM and again at 6:00 PM, every day for one week while the control group was not restrained (Fig. 2). On days one and six, $200 \mu \mathrm{L}$ of blood was collected (as described above) before and after the 30 minute treatment (restraint: placed in a bag after the first blood sample; control: put back in its cage after the first blood sample; Fig. 2). Samples were centrifuged and plasma was collected and stored at $-20^{\circ} \mathrm{C}$ until measured for T and CORT concentrations.

\subsection{Tissue collection and histology}

On day seven, all finches were weighed then sacrificed via isoflurane inhalation, followed by perfusion with saline $(0.9 \%$ sodium chloride in $0.1 \mathrm{M}$ phosphate buffer $(\mathrm{PB})$ 
with $0.1 \%$ sodium nitrite) and then $4 \%$ paraformaldehyde in $0.1 \mathrm{M}$ PB with $0.1 \%$ sodium nitrite. Their brains were extracted from the skull, then post-fixed and stored in $4 \%$ paraformaldehyde in $0.1 \mathrm{M} \mathrm{PB}$ at $4{ }^{\circ} \mathrm{C}$ overnight. The next day, brains were blotted dry, weighed to the nearest milligram, embedded in $8 \%$ gelatin and stored in $4 \%$ paraformaldehyde in $0.1 \mathrm{M}$ PB overnight at $4^{\circ} \mathrm{C}$. Embedded brains were transferred to $30 \%$ sucrose solution for 36 hours at $4^{\circ} \mathrm{C}$ and then frozen on dry ice and stored at $-80^{\circ} \mathrm{C}$ until sectioning.

Brains were sectioned coronally at $34 \mu \mathrm{m}$ on a cryostat $\left(-16^{\circ} \mathrm{C}\right)$ in four parallel series. Free-floating sections were stored in cryoprotectant solution (Watson et al., 1986) at $-20^{\circ} \mathrm{C}$ until processed. We immunostained sections containing $\mathrm{HVC}$ and RA from the first series of each brain for the neuronal marker NeuN to compare SCR volumes between restrained and control birds. Briefly, sections were rinsed in PB, incubated in a $0.5 \%$ hydrogen peroxide and $5 \%$ normal horse serum solution (Vector Labs, Burlingame, CA) for 1 hour, and then incubated in 1:10,000 mouse monoclonal anti-NeuN $\operatorname{IgG}$ (Chemicon International, Temecula, CA) in 0.3\% Triton X-100 (Fisher Scientific, Fair Lawn, NJ) in $0.1 \mathrm{M} \mathrm{PB}(\mathrm{PBT})$ overnight at $4^{\circ} \mathrm{C}$. The next day, sections were rinsed in PBT, incubated in 1:500 biotinylated anti-mouse IgG (Vector Labs) in PBT for 1 hour, rinsed in $\mathrm{PBT}$, incubated in $\mathrm{ABC}$ solution (Vector Labs) for 1 hour, and then rinsed in PBT. Immunoproducts were visualized by incubating sections in Vector SG chromagen solution (Vector Labs) for 2 minutes. Sections were rinsed in $0.9 \%$ sodium chloride (Fisher Scientific) in $0.01 \mathrm{M}$ PB (PBS), mounted onto slides, dried overnight, and coverslipped. To validate the specificity of the immunostaining procedure, control 
sections were incubated without primary or secondary antibody. No immunostaining was observed in any control section.

We then immunostained sections containing HVC from the second series of each brain for doublecortin (DCX), a marker of immature neurons (Boseret et al., 2007; Balthazart et al., 2008), to compare the density of new neurons in the HVC between restrained and control birds. Briefly, sections were rinsed in $\mathrm{PB}$, incubated in a $0.5 \%$ hydrogen peroxide and 5\% normal horse serum solution (Vector Labs, Burlingame, CA) for 1 hour, and then incubated in 1:2,000 doublecortin goat polyclonal IgG (Santa Cruz Biotechnology, Santa Cruz, CA) in PBT overnight at $4^{\circ} \mathrm{C}$. The next day, sections were rinsed in PBT, incubated in 1:100 biotinylated anti-goat $\operatorname{IgG}$ (Vector Labs) in PBT for 1 hour, rinsed in $\mathrm{PBT}$, incubated in $\mathrm{ABC}$ solution for 1 hour, and then rinsed in PBT. Immunoproducts were visualized by incubating sections in Vector SG chromagen solution for 2 minutes. Sections were rinsed in PBS, mounted onto slides, dried overnight, and coverslipped. To validate the specificity of the immunostaining procedure, control sections were incubated without primary or secondary antibody. No immunostaining was observed in any control section.

\subsection{SCR volumes and density of new neurons}

A Leica EZ4D microscope was used to digitize images of NeuN sections containing the HVC and RA. The cross sectional area of the HVC and RA was delineated from digital images and areas were electronically calculated using ImageJ version 1.410 
software (National Institutes of Health, USA). The area of each brain region was calculated for the left and right hemispheres on each section and then summed. Volumes were calculated by multiplying the summed areas by the distance separating consecutive sections $(136 \mu \mathrm{m})$. If a section was lost or damaged ( $\mathrm{n}=5$ out of 167 sections for HVC, $n=3$ out of 103 sections for RA), the corresponding measurement was replaced by the average of the two areas in the adjacent sections. All brain measurements were made without knowledge of the experimental treatment.

To determine the density of new neurons in the HVC, DCX-stained sections were examined at 200x magnification using an Olympus microscope, Model BX60, by an experimenter blind to the experimental treatment of the birds. DCX-ir cells were counted in 12 sampling frames placed in the HVC throughout the rostral to caudal extent of the nucleus. Cells were counted when a DCX-ir cell with a clear, unstained nucleus was visible and the cells did not touch the left or bottom side of the sampling frame. Each frame was $0.00264 \mathrm{~mm}^{3}$. The estimated total number of new neurons was then calculated by multiplying the density by the HVC volume.

\subsection{Radioimmunoassay}

Radioimmunoassay (RIA) was performed on blood plasma samples at Utah State University, Logan, UT. The total number of samples from the study required two RIAs, and the samples were randomly assigned to one of the RIAs. Plasma samples were assayed for $\mathrm{T}$ and CORT, using a previously described and established laboratory 
protocol (Moore, 1986). In brief, plasma was extracted using 30\% ethyl acetate/isooctane extractions. The $30 \%$ phase was separated, dried and resuspended in $10 \%$ ethyl acetate in isooctane. Individual hormones were separated from samples using packed columns. Different elutions of ethyl acetate/isooctane were added to the columns to separate out the different hormones ( $20 \%$ for T; $52 \%$ for CORT). Separated samples were collected in vials, dried and resuspended in PBS buffer. Duplicate aliquots of these samples were then assayed for T and CORT. The intra-assay coefficients of variation (CV) for the first assay were $7.1 \%$ for $\mathrm{T}$ and $14.4 \%$ for CORT; the intra-assay $\mathrm{CV}$ for the second assay were $8.6 \%$ for $\mathrm{T}$ and $7.7 \%$ for CORT. The inter-assay coefficients of variation were $7.1 \%$ for $\mathrm{T}$ and $13.5 \%$ for CORT.

\subsection{Data Analysis}

We used repeated measures ANOVA to examine the effect of time on circulating CORT and $\mathrm{T}$ concentrations from the acclimation period; plasma $\mathrm{T}$ concentrations were log-transformed for normality. We also performed a post hoc Tukey honestly significant difference (HSD) test to discern when CORT decreased.

To examine the effect of restraint stress on circulating CORT and $\mathrm{T}$ concentrations, we used 2-way repeated measures ANOVA; plasma $\mathrm{T}$ concentrations were square-root transformed. We performed sequential Bonferroni corrections and separate t-tests to determine the effect of group and time for Day 6 CORT concentrations. 
We conducted a student's t-test to determine the effect of group for SCR volumes and density of DCX-ir cells in the HVC. We used two-sample t-tests to see the effect of group on brain and testes weights.

The t-tests were performed using Minitab version 16.1.0.0 analyses software (Minitab Inc., USA), while repeated measures ANOVA and Tukey's HSD comparisons were performed using Statistica (Version 10; StatSoft Inc., Tulsa, OK, USA).

\section{Results}

\subsection{Acclimation}

Plasma CORT concentrations decreased during the one month acclimation period $(\mathrm{F}=7.98 ; \mathrm{df}=4,48 ; \mathrm{p}=0.00005 ;$ Fig. 3). By Week 3, plasma CORT values were significantly lower than those from Weeks 0 and 1 ( $p<0.022$ for all). Plasma $T$ levels were less than $1 \mathrm{ng} / \mathrm{ml}$ and did not change during the acclimation period (data not shown; $\mathrm{F}=1.24 ; \mathrm{df}=4,44 ; \mathrm{p}=0.31)$

\subsection{Restraint stress experiment}

Baseline $\mathrm{T}$ concentrations increased in both groups from day 1 to $6(\mathrm{~F}=10.52$; $\mathrm{df}=1,10 ; \mathrm{p}=0.009 ;$ Fig. 4) as expected due to increased day length on day 1 , and there were no differences in baseline values between groups ( $\mathrm{F}=0.09$; $\mathrm{df}=1,10 ; \mathrm{p}=0.76$; Fig. 4). 
On day $6, \mathrm{~T}$ concentrations decreased after treatment $(\mathrm{F}=9.58 ; \mathrm{df}=1,11 ; \mathrm{p}=0.01 ;$ Fig. 4$)$, and there were no differences between groups $(\mathrm{F}=0.87 ; \mathrm{df}=1,11 ; \mathrm{p}=0.37$; Fig. 4).

On day 1, there was no effect of group, time, or an interaction on plasma CORT concentrations (group: $\mathrm{F}=0.87 ; \mathrm{df}=1,9 ; \mathrm{p}=0.37$; time: $\mathrm{F}=0.38 ; \mathrm{df}=1,9 ; \mathrm{p}=0.54$; interaction: $\mathrm{F}=1.23 ; \mathrm{df}=1,9 ; \mathrm{p}=0.29 ;$ Fig. 5 ). On day 6 , there was no effect of group or time on plasma CORT concentrations $(\mathrm{F}=1.58 ; \mathrm{df}=1,11 ; \mathrm{p}=0.23$, and $\mathrm{F}=0.01 ; \mathrm{df}=1,11 ; \mathrm{p}=0.90$, respectively), however there was a significant interaction $(\mathrm{F}=24.5 ; \mathrm{df}=1,11 ; \mathrm{p}=0.004$; Fig. 5). Plasma CORT did not change in the control group $(t=-3.04 ; \mathrm{df}=5 ; \mathrm{p}=0.03 ;$ Fig. 5) but decreased in the restraint group $(\mathrm{t}=4.09 ; \mathrm{df}=6 ; \mathrm{p}=0.0063$; alpha $=0.0125)$. There was a difference in plasma CORT between groups at the 30 minute sample on day $6(t=3.04$; $\mathrm{df}=11 ; \mathrm{p}=0.011 ;$ Fig. 5$)$ but not at baseline $(\mathrm{t}=-0.82 ; \mathrm{df}=11 ; \mathrm{p}=0.43)$.

\subsection{SCR volumes and density of new neurons}

HVC volumes were smaller in the restraint group than the control group $(t=3.68$; $\mathrm{df}=10 ; \mathrm{p}=0.004$; Fig. 6). RA volumes were not different between control and restraint groups $(\mathrm{t}=1.07 ; \mathrm{df}=10 ; \mathrm{p}=0.31 ;$ Fig. 7$)$. There was not a difference in the density of new neurons $(t=-0.822 ; \mathrm{df}=9 ; \mathrm{p}=0.216$; Fig. 8$)$ or the estimated total number of new neurons $(t=0.121 ; \mathrm{df}=8 ; \mathrm{p}=0.453$; Fig. 9$)$ in the HVC between groups.

\subsection{Brain and testes weight}


Brain weight was not different between control and restraint groups $(\mathrm{t}=0.97$; $\mathrm{df}=11 ; \mathrm{p}=0.353$ ), which was expected because the HVC and RA are small and do not contribute very much to the overall brain weight (Brenowitz et al., 1991; Bernard and Ball, 1997). Brain weight was used as a control to ensure any differences in SCR volumes were not due to an overall effect of larger brains in one group.

Testes weight was not different between control and restraint groups $(\mathrm{t}=0.17$; $\mathrm{df}=10 ; \mathrm{p}=0.866)$.

\section{Discussion}

\subsection{Acclimation and baseline hormones}

Baseline CORT was high when birds were initially brought into captivity but decreased by the end of the four-week acclimation period (Fig 3). The decrease in baseline CORT could be due to a habituation to captivity (Cyr and Romero, 2009); however, this does not explain why the birds did not mount a stress response to restraint and/or handling on Day 1 of the stress week (Fig. 5). Conversely, if captivity served as a chronic stressor, CORT may have decreased during the acclimation period from attenuated activation of the HPA axis or a decrease in responsiveness of the adrenal gland to ACTH (Rich and Romero, 2005; Cyr and Romero, 2007). In free-living European Starlings, eight days of chronic stress is sufficient to reduce total baseline CORT and free baseline CORT (Cyr and Romero, 2007). Ten days of chronic stress is enough to decrease 
baseline CORT and acquire a repressed stress response in captive European Starlings (Rich and Romero, 2005). Birds in this study were given two weeks of acclimation before experimentation began; this study tested various stressors, but did not regard captivity itself or "acclimation to captivity" as possible stressors (Rich and Romero, 2005).

Plasma $\mathrm{T}$ was low throughout the acclimation period because the birds were held on short days, emulating winter conditions. This was expected because plasma $\mathrm{T}$ is naturally low during winter and peaks at the onset of spring, during photostimulation. This was seen once the restraint stress experiment started. On Day 1 of the stress experiment, $\mathrm{T}$ was low because it was the first day that lights were switched to long days. On Day 6 of the stress experiment, baseline $\mathrm{T}$ had increased in both groups due to photostimulation of the HPG axis (Fig. 4).

\subsection{Restraint stress experiment}

We hypothesized that stress would reduce neurogenesis and neuroplasticity in the SCRs of House Finches. This is because previous studies found that 1) high T contributes to the growth of SCRs seen in spring (Nottebohm, 1980; Brenowitz et al., 1991; Rasika et al., 1994; Gulledge and Deviche, 1997; Smith et al., 1997a; Sartor et al., 2005; Strand and Deviche, 2007), 2) CORT can decrease T (Dong et al., 2004; Deviche et al., 2010; also see review: Hardy et al., 2005), and 3) CORT is released during stress (Wingfield et al., $1982 ; 1983 ; 1994 ; 1995)$. Therefore, we predicted that stressed House Finches would have high CORT, low T, and smaller HVC volumes. 
If the finches had a repressed HPA axis at the end of the acclimation period, then neither group would have been able to mount a stress response to handling or restraint. This could explain why handling and/or restraint did not increase CORT on the first day of the restraint experiment (Fig. 5). Over the course of the six day experiment, control birds were left untouched while the restraint group was handled and restrained twice a day (Fig. 2). By the sixth day of the restraint experiment, control birds could have regained their HPA axis response, thus were able to mount a stress response to handling (Fig. 5). However, restrained birds could have maintained a compromised HPA axis due to repeated handling and restraint over the course of the six day experiment. This may explain why no birds had increased CORT after handling (for a blood sample) on Day 1 of the stress experiment and why only the control birds had increased CORT from handling on Day 6 (Fig. 5).

Repeated handling and/or restraint reduced the growth of the HVC by $28.2 \%$ (Fig. 6), but this effect was not mediated by CORT because CORT did not increase after restraint (Fig. 5). However, plasma $\mathrm{T}$ decreased after the 30 minute treatment in both groups by Day 6 - thus control birds experienced decreased $\mathrm{T}$ in response to handling during the blood sample and restrained birds experienced decreased $\mathrm{T}$ in response to handling and/or restraint (Fig. 4). Birds in the restraint group were handled and restrained twice per day for the whole week, while the control birds were only handled for blood samples on Day 1 and Day 6 (Fig. 2). Therefore, restrained birds may have incurred multiple decreases of plasma $\mathrm{T}$ throughout the week from handling and/or restraint stress, potentially lowering their total amount of $\mathrm{T}$ exposure over the six day period. This CORT- 
independent decrease in $\mathrm{T}$ possibly occurred via the release of beta-endorphin (review: Wingfield and Sapolsky, 2003) or by stress directly inhibiting the testes' ability to produce $\mathrm{T}$ via the nervous system (Deviche et al., 2010). The control birds did not experience these multiple decreases in $\mathrm{T}$ because they were not handled throughout the week, which may be the mechanism by which the HVC growth of restrained birds was stunted compared to that of the control birds.

Although HVC growth was more robust in the control group, there was no difference in the density or number of new neurons (Fig. 8 and 9). In another study, House Finches given T treatment had increased HVC volume but no increase in the number of new neurons (Strand and Deviche, 2007). Both studies support Nottebohm's proposal that high levels of plasma $T$ enhance the survival rate of neurons - not necessarily new neurons - in the HVC (Nottebohm, 2002).

We also measured the volume of another SCR, the RA. There was not a difference between restraint and control group RA volumes (Fig. 7). This result is not surprising because the RA needs longer than one week of long-day exposure to grow in response to the change in photoperiod and/or an increase in T (Brenowitz et al., 1991; Strand and Deviche, 2007). Had the birds been exposed to long days for two or more weeks, we may have seen a difference in RA volume between groups.

Stress may also affect other parts of the body, such as the weight of testes. Testes weight is important because it is positively correlated with stage of spermatogenesis in House Finches (Hamner, 1966). Gonadal development is enhanced by LH and FSH, both of which can be limited by stress (Wingfield and Sapolsky, 2003). Therefore, we thought 
the testes of restrained birds would weigh less. However, testes weight was not different between groups. Testes may not have been different between groups due to limited exposure to long days and not from an inability of stress to limit testes growth. One week exposure to long-days may be enough to increase House Finch HVC volume but may not be long enough to affect RA or testes volume. For example, Song Sparrows have enlarged HVC and RA volumes by late February, yet they have limited gonadal enlargement (less than $10 \%$ of breeding volume) at this time (Tramontin et al., 2001). HVC and RA enlargement also happens before gonadal enlargement in Corsican blue tits (Caro et al., 2005). Interestingly, plasma $\mathrm{T}$ increased by Day 6, before testes were maximally enlarged. Increased plasma $\mathrm{T}$ also precedes enlarged testes in Song Sparrows (Tramontin et al., 2001).

\subsection{Conclusions}

HVC growth due to photostimulation in adult male House Finches is attenuated by stressful conditions, like restraint, which is attributed to a stress-related decrease in $\mathrm{T}$ concentration. This decrease in plasma $\mathrm{T}$ does not seem to be dependent on CORT concentrations and therefore attributed to an aspect of stress other than CORT, such as the release of beta-endorphin and/or nervous system activation. Future studies should focus on the mechanisms of how stress and the associated hormonal changes affect neuroplasticity. 
Although early nutritional limitation has been shown to negatively affect neuroplasticity (Nowicki et al., 2002; Buchanan et al., 2003; Buchanan et al., 2004; MacDonald et al., 2006), it is unclear how stress in adulthood affects seasonal neuroplasticity. Restraint is often used to study the stress response of adult birds (Wingfield et al., 1992; Romero et al., 1997; Romero and Remage-Healey, 2000; Remage-Healey and Romero, 2001; Romero and Reed, 2005; Lynn and Porter, 2008). However, restraint may not be the most ecologically relevant stressor; food limitation during adulthood may be another option. Future studies might want to vary the stressor to reduce habituation or look at $\mathrm{T}$ and CORT over shorter time intervals to illustrate potential habituation or HPA axis repression/regaining in cumulative versus incremental fashion. 


\section{Figures}

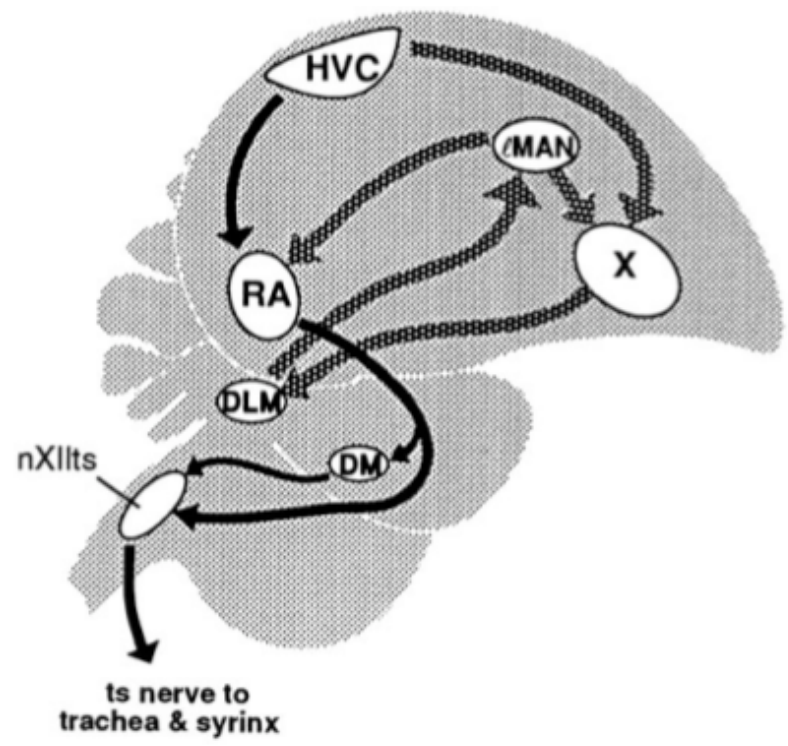

Figure 1. Schematic diagram of the songbird brain (Image from Nottebohm, 2002). The $\mathrm{HVC}$, which controls song learning, projects to the RA and Area X. The RA innervates the Tracheosyringeal portion of the XII cranial nerve, which controls the musculature for singing via the syrinx. Area $\mathrm{X}$ is involved in sensorimotor learning and song maintenance in adults (Scharff and Nottebohm, 1991; Brainard and Doupe, 2000a; 2000b; Balthazart et al., 2008).

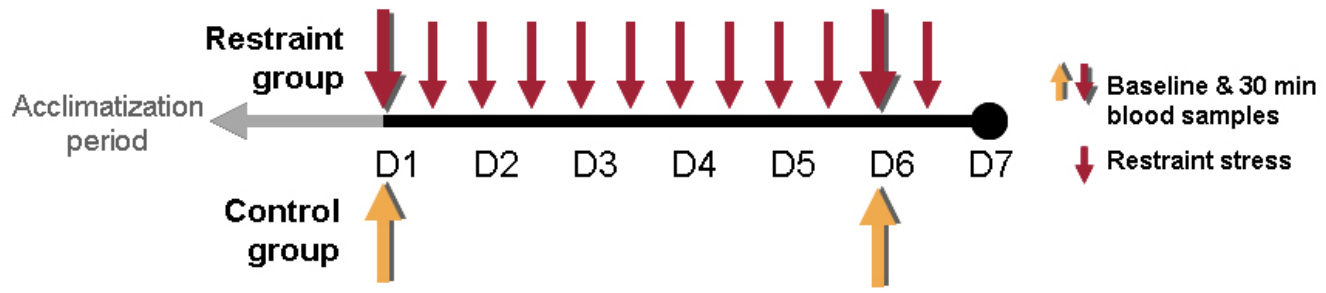

Figure 2. Timeline of restraint stress experiment. Small red arrows indicate restraint occurred. Large red arrows indicate blood was taken, birds were restrained for thirty minutes, and blood was taken a second time. Large yellow arrows indicate blood was taken before and after thirty minutes, but no restraint occurred. 


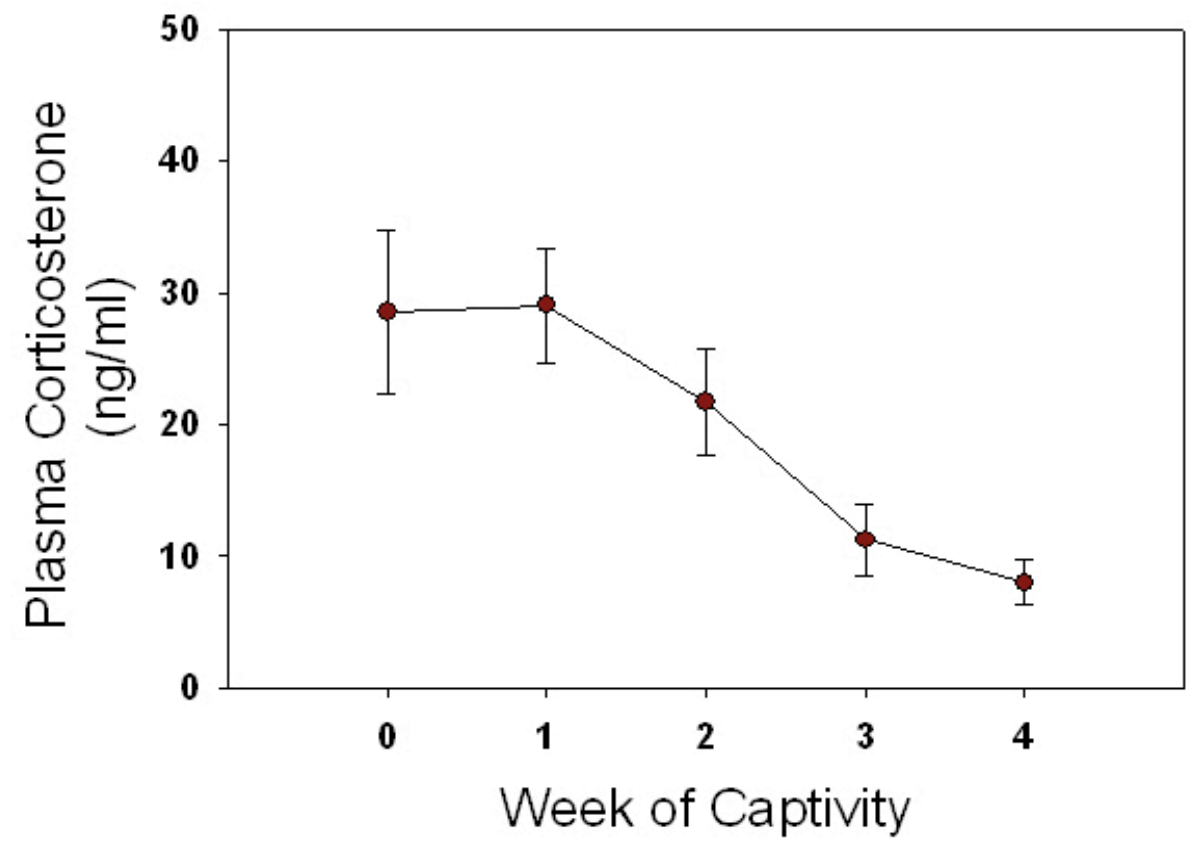

Figure 3. Plasma corticosterone ( $\mathrm{ng} / \mathrm{ml}$; mean $+/-\mathrm{se})$ in male House Finches during the four week acclimation period (short days, 8L:16D). 


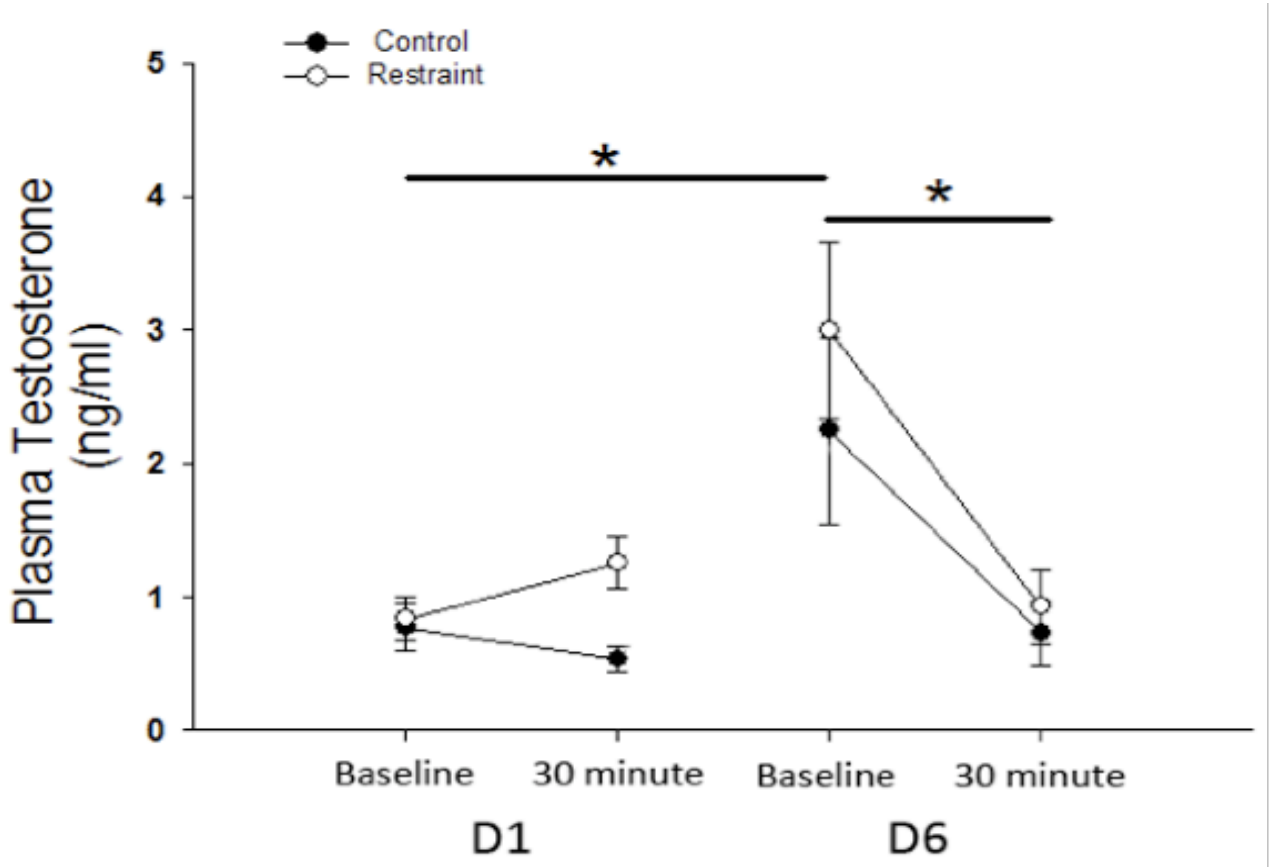

Figure 4. Plasma testosterone (ng/ml; mean +/- se) in male House Finches on days 1 (D1) and 6 (D6) of the restraint stress experiment. Prior to day 1, birds were maintained on short days (8L:16D); on day 1, the light schedule was changed to long days (16L:8D; photostimulated) and remained on long days throughout the experiment. Asterisk indicates effect of time in baseline T on days 1 and 6 and on day 6 (baseline vs. 30 minute samples) $(\mathrm{p}<0.01)$. 


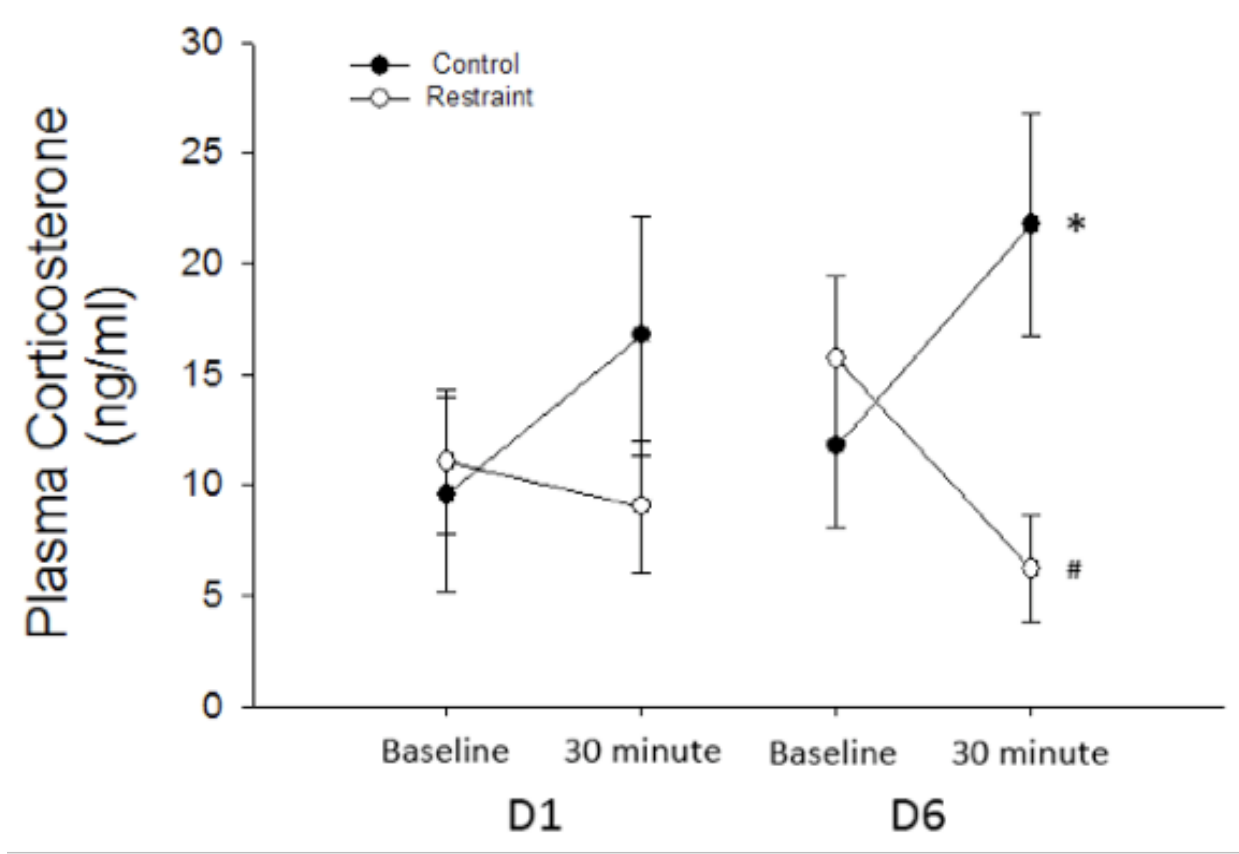

Figure 5. Plasma corticosterone (ng/ml; mean $+/-\mathrm{se}$ ) in male House Finches on day 1 and day 6 of the experiment before and 30 minutes after treatment. There are significant differences on day 6 between groups at 30 minutes and within groups from baseline $(\mathrm{p}<0.011)$.

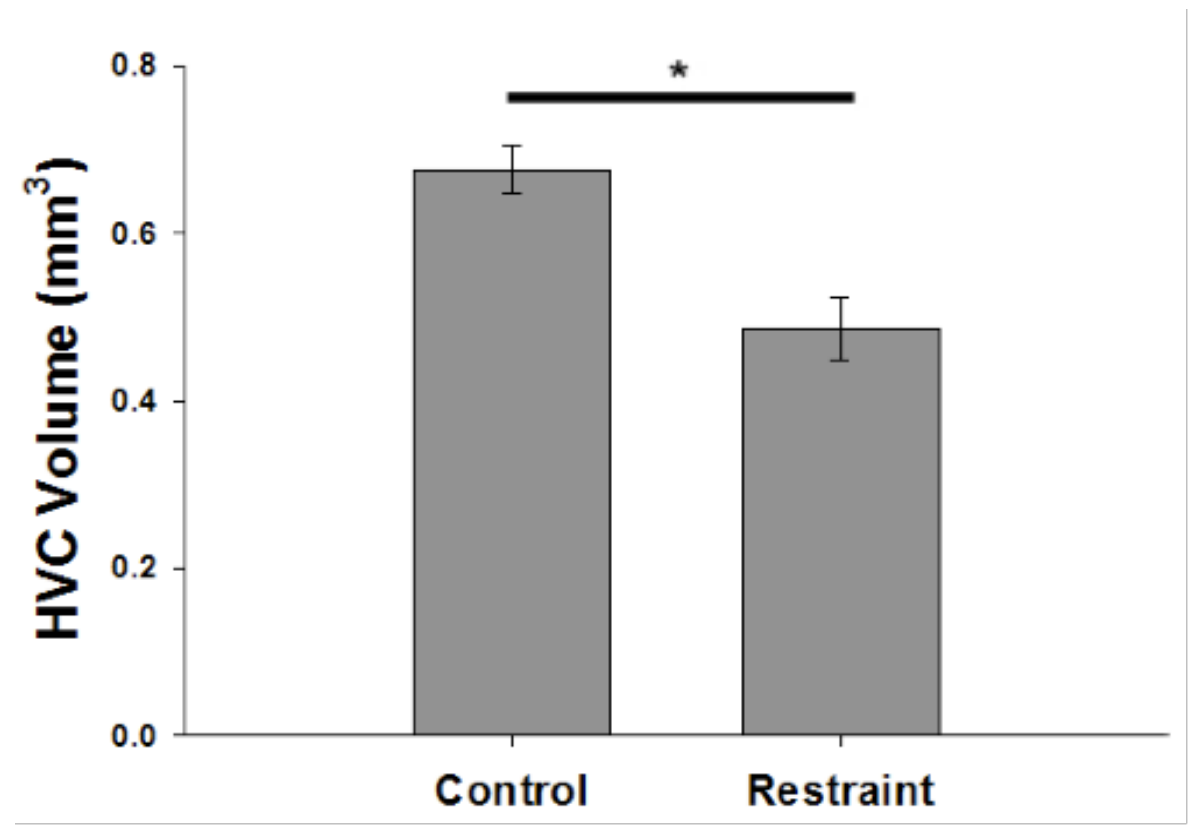

Figure 6. HVC volumes $\left(\mathrm{mm}^{3}\right.$; mean $\left.+\mathrm{se}\right)$ in the control and restraint group. Control birds had larger HVC volumes than restrained birds $(\mathrm{p}=0.004)$. 


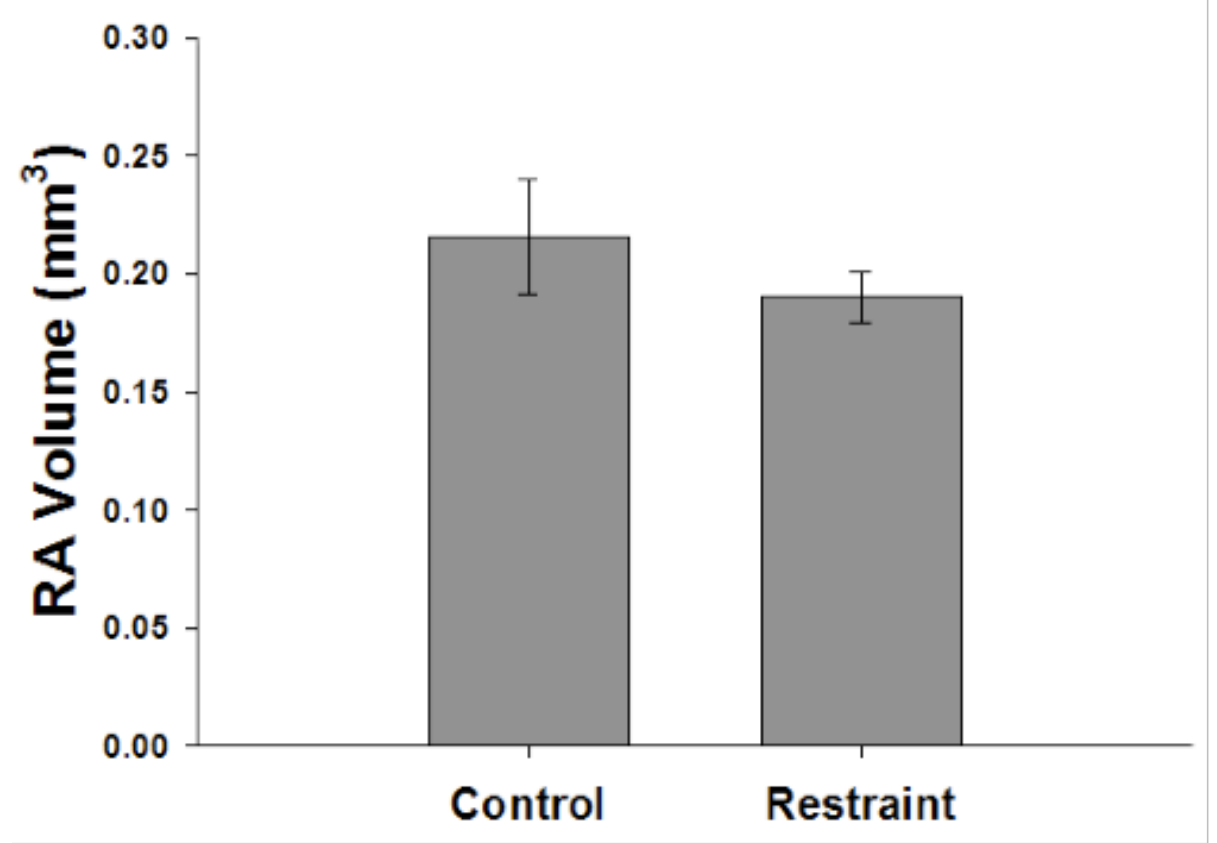

Figure 7. RA volumes $\left(\mathrm{mm}^{3}\right.$; mean $\left.+\mathrm{se}\right)$ in the control and restraint group $(\mathrm{p}=0.31)$.

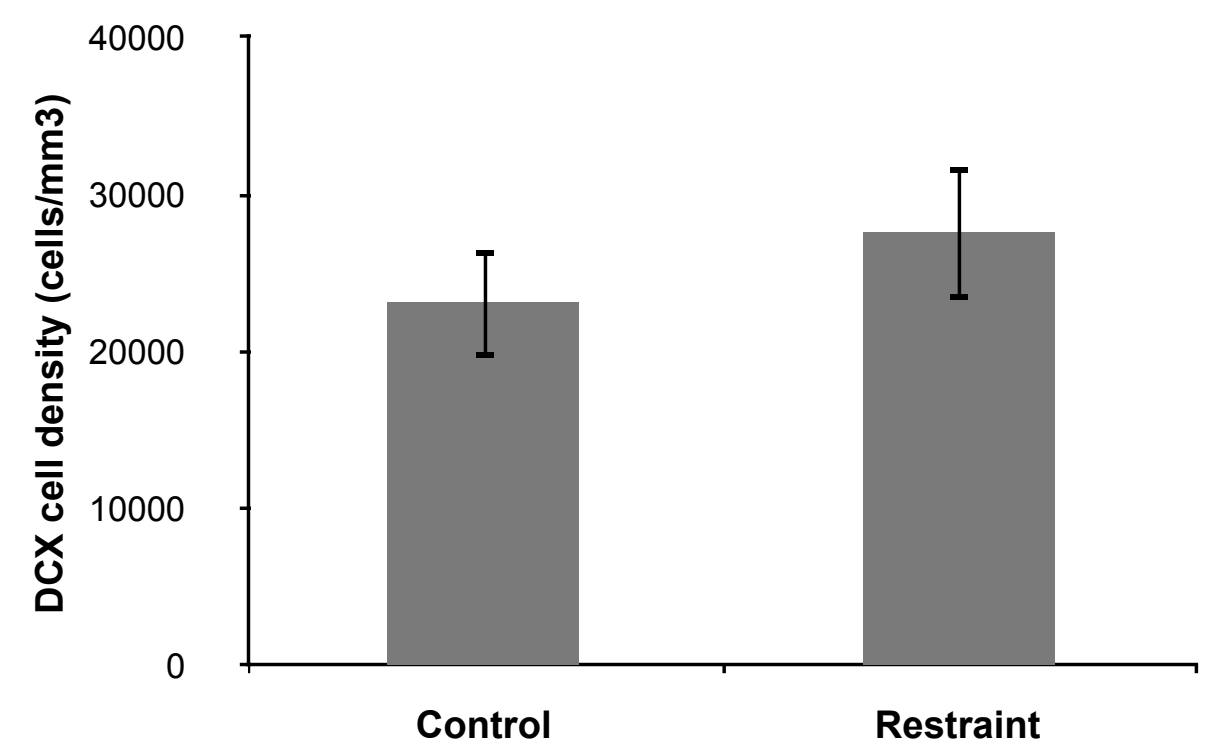

Figure 8. DCX cell density $\left(\right.$ cells $/ \mathrm{mm}^{3}$ ) in the HVC of control and restrained birds $(p=0.216)$. 


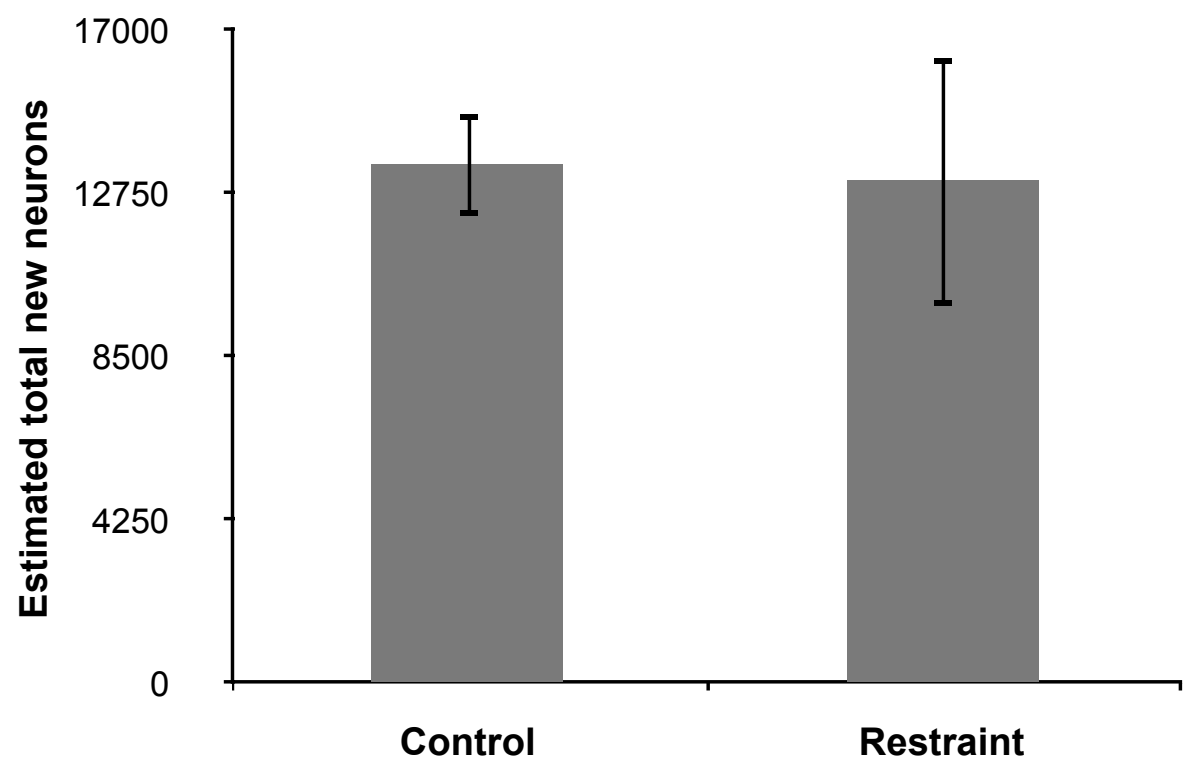

Figure 9. Estimated total of new neurons in the HVC of control and restrained birds $(p=0.453)$. 


\section{LIST OF REFERENCES}

Alvarez-Borda, B., Nottebohm, F. 2002. Gonads and singing play separate, additive roles in new neuron recruitment in adult canary brain. The Journal of Neuroscience 22(19): 8684-8690.

Ball, G.F., Balthazart, J. 2002. Neuroendocrine mechanisms regulating reproductive cycles and reproductive behavior in birds. In Hormones, Brain and Behavior, Vol. 2, D.W. Pfaff, A.P. Arnold, A.M. Etgen, R.T. Rubin, and S.E. Fahrbach, eds. Academic Press, Boston, pp. 649-798.

Ball, G.F., Riters, L.V., Balthazart, J. 2002. Neuroendocrinology of song behavior and avian brain plasticity: multiple sites of action of sex steroid hormones. Frontiers in Neuroendocrinology 23:137-178.

Balthazart, J., Boseret, G., Konkle, A.T.M., Hurley, L.L., Ball, G.F. 2008. Doublecortin as a marker of adult neuroplasticity in the canary song control nucleus HVC. European Journal of Neuroscience 27:801-817.

Banasr, M., Valentine, G.W., Li, X., Gourley, S.L., Taylor, J.R., Duman, R.S. 2007. Chronic unpredictable stress decreases cell proliferation in the cerebral cortex of the adult rat. Biological Psychiatry 62:496-504.

Bentley, G.E., Van't Hof, T.J., Ball, G.F. 1999. Seasonal neuroplasticity in the songbird telencephalon: a role for melatonin, Proceedings of the National Academy of Sciences U.S.A. $96: 4674-4679$.

Bentley, G.E., Wingfield, J.C., Morton, M.L., Ball, G.F. 2000. Stimulatory effects on the reproductive axis in female songbirds by conspecific and heterospecific male song. Hormones and Behavior 37:179-189.

Bergtold, W. H. 1913. A study of the House Finch. The Auk 30(1):40-73.

Bernard, D.J., Ball, G.F. 1997. Photoperiodic condition modulates the effects of testosterone on song control nuclei volumes in male European Starlings. General and Comparative Endocrinology 105:276-283.

Bernard, D.J., Ball, G.F., Wilson, F.E. 1994. Testosterone-dependent and -independent effects of photoperiod on the volume of song control nuclei in American tree sparrows. Society for Neuroscience, Abstract 24:163. 
Birkhead, T.R., Briskie, J.V., Moller, A.P. 1993. Male sperm reserves and copulation frequency in birds. Behavioral Ecology and Sociobiology 32:85-93.

Boseret, G., Ball, G.F., Balthazart, J. 2007. The microtubule-associated protein doublecortin is broadly expressed in the telencephalon of adult canaries. Journal of Chemical Neuroanatomy 33(3):140-154.

Brainard, M.S., Doupe, A.J. 2000a. Auditory feedback in learning and maintenance of vocal behaviour. Nature Reviews Neuroscience 1:31-40.

Brainard, M.S., Doupe, A.J. 2000b. Interruption of a basal ganglia- forebrain circuit prevents plasticity of learned vocalizations. Nature 404:762-766.

Brenowitz, E. A., Kroodsma, D. E. 1996. The neuroethology of birdsong. In Ecology and Evolution of Acoustic Communication in Birds, D.E. Kroodsma and E.H. Miller, eds. Cornell University Press, Ithaca, pp. 285-304.

Brenowitz, E. A., Margoliash, D., and Nordeen, K. W. 1997. Introduction to birdsong and the avian song system. Journal of Neurobiology 33:495-500.

Brenowitz, E.A., Nails, B., Wingfield, J.C., Kroodsma, D.E. 1991. Seasonal changes in avian song nuclei without seasonal changes in song repertoire. The Journal of Neuroscience 11(5):1367-1374.

Breuner, C.W., Orchinik, M. 2001. Seasonal regulation of membrane and intracellular corticosteroid receptors in the house sparrow brain. Journal of Neuroendocrinology $13: 412-420$.

Breuner, C.W., Orchinik, M., Hahn, T.P., Meddle, S.L., Moore, I.T., Owen-Ashley, N.T., Sperry, T.S., Wingfield, J.C. 2003. Differential mechanisms for regulation of the stress response across latitude gradients. American Journal of Physiology- Regulatory, Integrative and Comparative Physiology 285:R594-R600.

Buchanan K.L., Leitner S., Spencer K.A., Goldsmith A.R., Catchpole C.K. 2004. Developmental stress selectively affects the song control nucleus HVC in the zebra finch. Proceedings of the Royal Society B 271:2381-2386.

Buchanan, K.L., Spencer, K.A., Goldsmith, A.R., Catchpole, C.K. 2003. Song as an honest signal of past developmental stress in the European starling (Sturnus vulgaris). Proceedings of the Royal Society B 270:1149-1156. 
Burger, J.W. 1942. The influence of some external factors on the ovarian cycle of the female starling. Anatomical record, Abstract 84(4):518.

Cameron, H.A., Gould, E. 1994. Adult neurogenesis is regulated by adrenal steroids in the dentate gyrus. Neuroscience 61(2):203-209.

Caro, S.P., Lambrechts, M.M., Balthazart, J. 2005. Early seasonal development of brain song control nuclei in male blue tits. Neuroscience Letters 386:139-144.

Caro, S.P., Sewall, K.B., Salvante, K.G., Sockman, K.W. 2010. Female Lincoln's sparrows modulate their behavior in response to variation in male song quality. Behavioral Ecology 21:562-569.

Casto, J.M., Nolan, V.Jr., Ketterson, E.D. 2001. Steroid hormones and immune function: experimental studies in wild and captive dark-eyed juncos (Junco hyemalis). The American Naturalist 157(4):408-420.

Catchpole, C. K. 1973. The functions of advertising song in the Sedge warbler (Acrocephalus schoenobaenus) and reed warbler (A. scirpacceus). Behaviour 46:300-320.

Cox, P.R. 1944. A statistical investigation into bird-song. British Birds 38:3-9.

Cyr, N.E., Romero, L.M. 2007. Chronic stress in free-living European starlings reduces corticosterone concentrations and reproductive success. General and Comparative Endocrinology 151:82-89.

Cyr, N.E., Romero, L.M. 2009. Identifying hormonal habituation in field studies of stress. General and Comparative Endocrinology 161:295-303.

Dawson, A., King, V.M., Bentley, G.E., Ball, G.F. 2001. Photoperiodic control of seasonality in birds. Journal of Biological Rhythms 16:365.

Deviche, P.J., Hurley, L.L., Fokidis, H.B., Lerbour, B., Silverin, B., Silverin, B., Sabo, J., Sharp, P.J. 2010. Acute stress rapidly decreases plasma testosterone in a free-ranging male songbird: potential site of action and mechanism. General and Comparative Endocrinology 169:82-90.

Deviche, P., Wingfield, J.C., Sharp, P.J. 2000. Year-class differences in the reproductive system, plasma prolactin and corticosterone concentrations, and onset of prebasic molt in male dark-eyed juncos (Junco hyemalis) during the breeding period. General and Comparative Endocrinology 118:425-435. 
Dloniak, S.M., Deviche, P. 2001. Effects of testosterone and photoperiodic condition on song production and vocal control region volumes in adult male dark-eyed juncos (Junco hyemalis). Hormones and Behavior 39(2):95-105.

Dong, Q., Salva, A., Sottas, C.M., Niu, E., Holmes, M., Hardy, M.P. 2004. Rapid glucocorticoid mediation of suppressed testosterone biosynthesis in male mice subjected to immobilization stress. Journal of Andrology 25(6):973-981.

Dufty Jr., A.M., Wingfield, J.C. 1986. Temporal patterns of circulating luteinizing and steroid hormones in a brood parasite the brownheaded cowbird molothrus-ater I. Males. Journal of Zoology, Series A 208:191-204.

Elekonich, M.M., Wingfield, J.C. 2000. Seasonality and hormonal control of territorial aggression in female song sparrows (Passeriformes: Emberizidae: Melospiza melodia). Ethology 106:493-510.

Erickson, C.J., Lehrman, D.S. 1964. Effect of castration of male ring doves upon ovarian activity of females. Journal of Comparative and Physiological Psychology 58(2):164-166.

Evenden, F.G. 1957. Observations on nesting behavior of the house finch. Condor 59:112-117.

Gould E., Tanapat P., McEwen B. S., Flugge G., Fuchs E. 1998. Proliferation of granule cell precursors in the dentate gyrus of adult monkeys is diminished by stress. Proceedings of the National Academy of Sciences, USA 95:3168.

Gulledge, C.C., Deviche, P. 1997. Androgen control of vocal control region volumes in a wild migratory songbird (Junco hyemalis) is region and possibly age dependent. Journal of Neurobiology 32:391-402.

Gulledge, C.C., Deviche, P. 1998. Photoperiod and testosterone independently affect vocal control region volumes in adolescent male songbirds. Journal of Neurobiology 36:550-558.

Hahn, T.P., Boswell, T., Wingfield, J.C., Ball, G.F. 1997. Temporal flexibility in avian reproduction. In Patterns and Mechanism. Vol. 14. V.J. Nolan, E.D. Ketterson, and C.F. Thompson, eds. Plenum Press, New York, pp. 39-80.

Hamner, W.M. 1966. Photoperiodic control of the annual testicular cycle in the house finch, Carpodacus mexicanus. General and Comparative Endocrinology 7(2):224-233. 
Hamner, W.M. 1968. The photorefractory period of the house finch. Ecology 49(2): 211-227.

Hardy, M.P., Gao, H., Dong, Q., Ge, R., Wang, Q., Chai, W.R., Feng, X., Sottas, C. 2005. Stress hormone and male reproductive function. Cell and tissue research 322(1):147-153.

Harvey, S., Phillips, J.G., Rees, A., Hal, T.R. 1984. Stress and adrenal function. Journal of Experimental Zoology 232:633-646.

Hegner, R.E., Wingfield, J.C. 1987. Effects of experimental manipulation of testosterone levels on parental investment and breeding success in male house sparrows. The Auk 104(3):462-469.

Hill, G.E. 1991. Plumage coloration is a sexually selected indicator of male quality. Nature 350:337-339.

Hill, G.E. 1993. House finch (Carpodacus mexicanus), the birds of North America Online. A. Poole, ed. Ithaca: Cornell Lab of Ornithology; Retrieved from the Birds of North America Online: < http://bna.birds.cornell.edu/bna/species/046>.

doi: $10.2173 /$ bna.46

Johnsen, T.S. 1998. Behavioural correlates of testosterone and seasonal changes of steroids in red-winged blackbirds. Animal Behaviour 55:957-965.

Ketterson, E.D., Nolan, V.Jr., Wolf, L., Ziegenfus, C. 1992. Testosterone and avian life histories: effects of experimentally elevated testosterone on behavior and correlates of fitness in the dark-eyed junco (Junco hyemalis). The American Naturalist 140(6): 980-999.

Kirn, J.R., Clower, R.P., Kroodsma, D.E., DeVoogd, T.J. 1989. Song-related brain regions in the red-winged blackbird are affected by sex and season but not repertoire size. Journal of Neurobiology 20(3):139-163.

Kirn, J., O'Loughlin, B., Kasparian, S., Nottebohm, F. 1994. Cell death and neuronal recruitment in the high vocal center of adult male canaries are temporally related to changes in song. Proceedings of the National Academy of Sciences, USA 91:7844-7848.

Kotrschal, K., Hirschenhauser, K., Moestl, E. 1998. The relationship between social stress and dominance is seasonal in greylag geese. Animal Behaviour 55:171-176.

Kroodsma, D.E. 1976. Reproductive development in a female songbird: differential stimulation by quality of male song. Science 192(4239):574-575. 
Leitner, S., Catchpole, C.K. 2002. Female Canaries that respond and discriminate more between male songs of different quality have a larger song control nucleus (HVC) in the brain. Journal of Neurobiology 52(4):294-301.

Li, R., Taniguchi, I., Sakaguchi, H. 2000. Auditory-vocal cholinergic pathway in the songbird brain. Canadian Journal of Physiology and Pharmacology 78:1072-1076.

Logan, C. A. 1983. Reproductively dependent song cyclicity in mated male mockingbirds (Mimus polyglotts). The Auk 100:404-413.

Lott, D.F., Brody, P.N. 1966. Support of ovulation in the ring dove by auditory and visual stimuli. Journal of Comparative and Physiological Psychology 62(2):311-313.

Lynn, S.E., Porter, A.J. 2008. Trapping initiates stress response in breeding and nonbreeding house sparrows Passer domesticus: implications for using unmonitored traps in field studies. Journal of Avian Biology 39:87-94.

MacDonald, I.F., Kempster, B., Zanette, L., MacDougall-Shackleton, S.A. 2006. Early nutritional stress impairs development of a song-control brain region in both male and female juvenile song sparrows (Melospiza melodia) at the onset of song learning. Proceedings of the Royal Society B 273:2559-2564.

Malberg, J.E., Duman, R.S. 2003. Cell proliferation in adult hippocampus is decreased by inescapable stress: reversal by fluoxetine treatment. Neuropsychopharmacology 28:1562-1571.

Maney, D.L., MacDougall-Shackleton, E.A., MacDougall-Shackleton, S.A., Ball, G.F., Hahn, T.P. 2003. Immediate early gene response to hearing song correlates with receptive behavior and depends on dialect in a female songbird. Journal of Comparative Physiology A 189:667-674.

Margoliash, D. 1997. Functional organization of forebrain pathways for song production and perception. Journal of Neurobiology 33:671-693.

Meitzen, J., Thompson, C.K. 2008. Seasonal-like growth and regression of the avian song control system: neural and behavioral plasticity in adult male Gambel's white-crowned sparrows. General and Comparative Endocrinology 157:259-265.

Mennill, D.J., Badyaev, A.V., Jonart, L.M., Hill, G.E. 2006. Male house finches with elaborate songs have higher reproductive performance. Ethology 112:174-180. 
Moore, M.C. 1986. Elevated testosterone levels during nonbreeding-season territoriality in a fall-breeding lizard, Sceloporus jarrovi. Journal of Comparative Physiology A 158:159-163.

Morton, M.L. 1976. Adaptive strategies of Zonotrichia breeding at high latitude or high altitude. In Proceedings of the 16th International Ornithological Congress. H.J. Frith and J.H. Calaby, eds. Australian Academy of Science, Canberra, pp. 322-336.

Morton, M.L., Pereyra, M.E., Baptista, L.F. 1985. Photoperiodically induced ovarian growth in the white-crowned sparrow (Zonotrichia leucophrys gambelii) and its augmentation by song. Comparative Biochemistry and Physiology 80A(1):93-97.

Nolan, P.M., Hill, G.E. 2004. Female choice for song characteristics in the house finch. Animal Behaviour 67:403-410.

Nordeen, K. W., Nordeen, E. J. 1992. Auditory feedback is necessary for the maintenance of stereotyped song in adult zebra finches. Behavioral and Neural Biology 57:58-66.

Nottebohm, F. 1975. Vocal behavior in birds. In Avian Biology, D.S. Farner and J.F. King, eds. Vol. 5, Academic Press, New York, pp. 287-332.

Nottebohm, F. 1980. Testosterone triggers growth of brain vocal control nuclei in adult female canaries. Brain research 189(2):429-436.

Nottebohm, F. 1981. A brain for all seasons: cyclical anatomical changes in song control nuclei of the canary brain. Science 214(4527):1368-1370.

Nottebohm, F. 2002. Why are some neurons replaced in adult brain? The Journal of Neuroscience 22(3):624-628.

Nottebohm, F., Nottebohm, M. E., Crane, L. A. 1986. Developmental and seasonal changes in canary song and their relation to changes in the anatomy of song-control nuclei. Behavioral and Neural Biology 46:445-471.

Nottebohm, F., Nottebohm, M. E., Crane, L. A., Wingfield, J. C. 1987. Seasonal changes in gonadal hormone levels of adult male canaries and their relation to song. Behavioral and Neural Biology 47:197-221.

Nottebohm, F., Stokes, T. M., Leonard, C. M. 1976. Central control of song in the canary, Serinus canarius. The Journal of Comparative Neurology 165:457-486. 
Nowicki, S., Searcy, W.A. 2004. Song function and the evolution of female preferences: why birds sing, why brains matter. Behavioral Neurobiology of Birdsong 1016:704-723.

Nowicki, S., Searcy, W.A., Peters, S. 2002. Brain development, song learning and mate choice in birds: a review and experimental test of the "nutritional stress hypothesis." Journal of Comparative Physiology A 188:1003-1014.

Nowicki, S., Peters, S., Podos, J. 1998. Song learning, early nutrition and sexual selection in songbirds. American Zoologist 38:179-190.

OReilly, M. 1995. Ecological basis of endocrine phenomena: field studies of Scolopacidae as model systems. University of Washington Thesis, Department of Zoology, Seattle.

Polikarpova, E. 1940. Influence of external factors upon the development of the sexual gland of the sparrow. CR Acad. Sci. U.R.S.S. 26:91-95.

Rasika, S., Nottebohm, F., Alvarez-Buylla, A. 1994. Testosterone increases the recruitment and/or survival of new high vocal center neurons in adult female canaries. Proceedings of the National Academy of Sciences, USA 91:7854-7858.

Remage-Healey, L., Romero, M.L. 2001. Corticosterone and insulin interact to regulate glucose and triglyceride levels during stress in a bird. American Journal of PhysiologyRegulatory, Integrative and Comparative Physiology 281:R994-R1003.

Rich, E. L., Romero, L. M. 2005. Exposure to chronic stress downregulates corticosterone responses to acute stressors. American Journal of Physiology - Regulatory, Integrative and Comparative Physiology 288:R1628-R1636.

Romero, L.M. 2006. Seasonal changes in hypothalamic-pituitary-adrenal axis sensitivity in free-living house sparrows (Passer domesticus). General and Comparative Endocrinology 149:66-71.

Romero, L.M., Ramenofsky, M., Wingfield, J.C. 1997. Season and migration alters the corticosterone response to capture and handling in an arctic migrant, the white-crowned sparrow (Zonotrichia leucophrys gambelii). Comparative Biochemistry and Physiology C 116:171-177.

Romero, L.M., Reed, J.M. 2005. Collecting baseline corticosterone samples in the field: is under 3 min good enough? Comparative Biochemistry and Physiology, Part A 140:73-79. 
Romero, M.L., Remage-Healey, L. 2000. Daily and seasonal variation in response to stress in captive starlings (Sturnus vulgaris): Corticosterone. General and Comparative Endocrinology 119:52-59.

Romero, L.M., Soma, K.K., Wingfield, J.C. 1998a. Changes in pituitary and adrenal sensitivities allow the snow bunting (Plectrophenax nivalis), an arctic-breeding song bird, to modulate corticosterone release seasonally. Journal of Comparative Physiology B 168:353-358.

Romero, L.M., Soma, K.K., Wingfield, J.C., 1998b. Hypothalamic-pituitary-adrenal axis changes allow seasonal modulation of corticosterone in a bird. American Journal of Physiology 274:R1338-R1344.

Romero, L.M., Soma, K.K., Wingfield, J.C. 1998c. The hypothalamus and adrenal regulate modulation of corticosterone release in redpolls (Carduelis flammea - an arcticbreeding song bird). General and Comparative Endocrinology 109:347-355.

Romero, L.M., Wingfield, J.C. 1998. Seasonal changes in adrenal sensitivity alter corticosterone levels in Gambels white-crowned sparrows (Zonotrichia leucophyrys gambelii). Comparative Biochemistry and Physiology C 119:31-36.

Romero, L.M., Wingfield, J.C. 1999. Alterations in hypothalamic-pituitary-adrenal function associated with captivity in Gambels white-crowned sparrows (Zonotrichia leucophrys gambelii). Comparative Biochemistry and Physiology B 122:13-20.

Sartor, J. J., Ball, G. F. 2005. Social suppression of song is associated with a reduction in volume of a song-control nucleus in European Starlings (Sturnus vulgaris). Behavioral Neuroscience 119(1):233-244.

Sartor, J.J., Balthazart, J., Ball, G.F. 2005. Coordinated and dissociated effects of testosterone on singing behavior and song control nuclei in canaries (Serinus canaria). Hormones and Behavior 47:467-476.

Scharff, C., Nottebohm, F. 1991. A comparative study of the behavioral deficits following lesions of various parts of the zebra finch song system: implications for vocal learning. The Journal of Neuroscience 11(9):2896-2913.

Searcy, W.A., Andersson, M. 1986. Sexual selection and the evolution of song. Annual Review of Ecology and Systematics 17:507-533.

Searcy, W.A., Marler, P. 1981. A test for responsiveness to song structure and programming in female sparrows. Science 213(4510):926-928. 
Siegel, H.S. 1980. Physiological stress in birds. BioScience 30:529-534.

Slagsvold, T. 1977. Bird song activity in relation to breeding cycle, spring weather, and environmental physiology. Ornis Scandinavica 8:197-222.

Smith, G. T. 1996. Seasonal plasticity in the song nuclei of wild rufous-sided towhees. Brain Research 734(1-3):79-85.

Smith, G.T., Brenowitz, E.A., Beecher, M.D., Wingfield, J.C. 1997a. Seasonal changes in testosterone, neural attributes of song control nuclei, and song structure in wile songbirds. The Journal of Neuroscience 17(15):6001-6010.

Smith, G.T., Brenowitz, E.A., Wingfield, J.C. 1997b. Seasonal changes in the size of the avian song control nucleus HVC defined by multiple histological markers. Journal of Comparative Neurology 381:253-261.

Smith, G. T., Brenowitz, E. A., Wingfield, J. C., Baptista, L. F. 1995. Seasonal changes in song nuclei and song behavior in Gambel's white-crowned sparrows. Journal of Neurobiology 28(1):114-125.

Sockman, K.W., Williams, T.D., Dawson, A., Ball, G.F. 2004. Prior experience with photostimulation enhances photo-induced reproductive development in female european starlings: a possible basis for the age-related increase in avian reproductive performance. Biology of Reproduction 71:979-986.

Strand, C.R., Deviche, P. 2007. Hormonal and environmental control of song control region growth and new neuron addition in adult male House Finches, Carpodacus mexicanus. Developmental Neurobiology 67:827-837.

Strand, C.R., Ross, M.S., Weiss, S.L., Deviche, P. 2008. Testosterone and social context affect singing behavior but not song control region volumes in adult male songbirds in the fall. Behavioural Processes 78:29-37.

Thompson, W.L. 1960. Agnostic behavior in the House Finch. Part I: annual cycle and display patterns. Condor 62:245-271.

Tramontin, A.D., Hartman, V.N., Brenowitz, E.A. 2000. Breeding conditions induce rapid and sequential growth in adult avian song control circuits: a model of seasonal plasticity in the brain. The Journal of Neuroscience 20(2):854-861. 
Tramontin, A.D., Perfito, N., Wingfield, J.C., Brenowitz, E.A. 2001. Seasonal growth of song control nuclei precedes seasonal reproductive development in wild adult song sparrows. General and Comparative Endocrinology 122:1-9.

Tuttle, E.M., Pruett-Jones, S., Webster, M.S. 1996. Cloacal protuberances and extreme sperm production in australian fairy-wrens. Proceedings of the Royal Society B 263(1375):1359-1364.

Vallet, E., Kreutzer, M. 1995. Female canaries are sexually responsive to special song phrases. Animal Behaviour 49:1603-1610.

Vicario, D.S. 1991. Neural mechanisms of vocal production in songbirds. Current Opinion in Neurobiology 1:595-600.

Wada, M., Shimizu, T., Kobayashi, S., Yatani, A., Sandaiji, Y., Ishikawa, T., Takemure, E. 1999. Behavioral and hormonal basis of polygynous breeding in male bush warblers (Cettia diphone). General and Comparative Endocrinology 116:422-432.

Watson, R.E., Wiegand, S.J., Cloug, R.W., Hoffman, G.E. 1986. Use of cryoprotectant to maintain long-term peptide immunoreactivity and tissue morphology. Peptides 7:155-159.

Whitfield-Rucker, M., Cassone, V.M. 2000. Photoperiodic regulation of the male house sparrow song control system: gonadal dependent and independent mechanisms. General and Comparative Endocrinology 118:173-183.

Wilson, F.E., Donham, R.S. 1988. Daylength and control of seasonal reproduction in male birds. In Processing of environmental information in vertebrates. M.H. Stetson, ed. Springer-Verlag, New York, pp. 101-119.

Wingfield, J.C. 1984a. Androgens and mating systems: testosterone-induced polygyny in normally monogamous birds. The Auk 101(4):665-671.

Wingfield, J.C. 1984b. Environmental and endocrine control of reproduction in the song sparrow, Melospiza melodia I. Temporal organization of the breeding cycle. General and Comparative Endocrinology 56(3):406-416.

Wingfield, J.C. 1985a. Influences of weather on reproductive function in female Song sparrows, Melospiza melodia. Journal of Zoology (London) 205:545-558.

Wingfield, J.C. 1985b. Influences of weather on reproductive function in male Song sparrows, Melospiza melodia. Journal of Zoology (London) 205:525-544. 
Wingfield, J.C., Deviche, P., Sharbaugh, S., Astheimer, L.B., Holberton, R., Suydam, R., Hunt, K. 1994. Seasonal changes of the adrenocortical responses to stress in redpolls, Acanthis flammea, in Alaska. The Journal of Experimental Zoology 270:372-380.

Wingfield, J.C., Farner, D.S. 1978. The annual cycle in plasma irLH and steroid hormones in feral populations of the white-crowned sparrow, Zonotrichia leucophrys gambelii. Biology of Reproduction 19:1046-1056.

Wingfield, J.C., Farner, D.S. 1979. Some endocrine correlates of renesting after loss of clutch or brood in the white-crowned sparrow, Zonotrichia leucophrys gambelii. General and Comparative Endocrinology 38:322-331.

Wingfield, J.C., Hegner, R.E., Dufty, A.M.Jr., Ball, G.F. 1990. The “challenge hypothesis": theoretical implications for patterns of testosterone secretion, mating systems, and breeding strategies. The American Naturalist 136(6):829-846.

Wingfield, J.C., Kubokawa, K., Ishida, K., Ishii, S., Wada, M. 1995. The adrenocortical response to stress in male bush warblers, Cettia diphone: a comparison of breeding populations in Honshu and Hokkaido, Japan. Zoological Science 12:615-621.

Wingfield, J.C., Moore, M.C., Farner, D.S. 1983. Endocrine responses to inclement weather in naturally breading populations of white-crowned sparrows (Zonotrichia leucophrys pugetensis). The Auk 100(1):56-62.

Wingfield, J.C., Sapolsky, R.M. 2003. Reproduction and resistance to stress: when and how. Journal of Neuroendocrinology 15:711-724.

Wingfield, J.C., Smith, J.P., Farner, D.S. 1982. Endocrine responses of white-crowned sparrows to environmental stress. Condor 84(4):399-409.

Wingfield, J.C., Vleck, C.M., Moore, M.C. 1992. Seasonal changes of the adrenocortical response to stress in birds of the Sonoran desert. The Journal of Experimental Zoology 264:419-428.

Wolfson, A. 1954. Notes on the cloacal protuberance, seminal vesicles, and a possible copulatory organ in male passerine birds. Bulletin of the Chicago Academy of Sciences 10(1):1-23. 